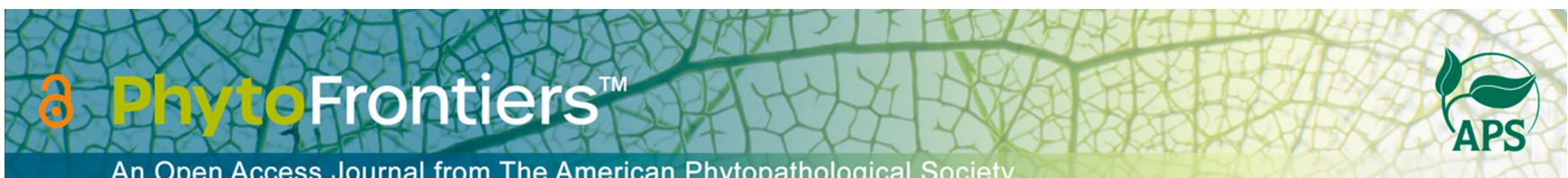

\title{
Research
}

\section{Xanthomonas campestris pv. musacearum Bacterial Infection Induces Organ-Specific Callose and Hydrogen Peroxide Production in Banana}

\author{
Abubakar Sadik Mustafa ${ }^{1}$ (i) | Benison Tugume ${ }^{1}$ | Jamilu E. Ssenku | Paul Ssemanda ${ }^{1}$ | \\ Shahasi Y. Athman ${ }^{1}$ | Hannington Oryem-Origa ${ }^{1,2}$ | Jerome Kubiriba ${ }^{3}$ | Savithramma P. Dinesh-Kumar ${ }^{4}$ | \\ Arthur K. Tugume ${ }^{1,+}$ (D) |
}

\footnotetext{
${ }^{1}$ Department of Plant Sciences, Microbiology and Biotechnology, College of Natural Sciences, Makerere University, Kampala, P. O. Box 7062, Uganda

2 Department of Biological Sciences, Faculty of Science, Islamic University in Uganda, Mbale, P.O. Box 2555, Uganda

${ }^{3}$ National Banana Research Program, National Agricultural Research Organization (NARO), Kampala, P.O. Box 7065, Uganda

${ }^{4}$ Department of Plant Biology and The Genome Center, College of Biological Sciences, University of California, Davis, CA, U.S.A.
}

† Corresponding author: A. K. Tugume; arthur.tugume@mak.ac.ug

Accepted for publication 3 January 2022.

\section{Funding}

Funding was provided by Bill and Melinda Gates Foundation (INV-009894).

$e$-Xtra: Supplementary material is available online.

The author(s) declare no conflict of interest.

\section{Abstract}

Xanthomonas campestris pv. musacearum $(X \mathrm{~cm})$ bacteria cause banana Xanthomonas wilt (BXW), the most destructive disease of bananas in East and Central Africa. During early stages of infection in susceptible banana cultivars, incomplete systemic movement of $\mathrm{Xcm}$ limits bacterial colonization in the upper organs. The mechanistic basis of this delayed movement is unknown. We hypothesized that $\mathrm{Xcm}$ infection triggers basal pattern-triggered immune (PTI) responses whose spatial and temporal variability along the banana's anatomical structure accounts for initially limiting $\mathrm{Xcm}$ in upper organs. Hence, we examined PTI responses such as callose deposition and hydrogen peroxide $\left(\mathrm{H}_{2} \mathrm{O}_{2}\right)$ production in different organs in response to $\mathrm{Xcm}$ infection in BXW-susceptible Kayinja and Mbwazirume banana cultivars and wild resistant progenitor Musa balbisiana. $X \mathrm{~cm}$-induced callose increased and peaked at 14 days postinoculation (dpi) and $28 \mathrm{dpi}$ as assessed by fluorescence microscopy and enzyme-linked immunosorbent assays, respectively. The levels of $\mathrm{Xcm}$-induced $\mathrm{H}_{2} \mathrm{O}_{2}$ and callose were highest in the pseudostems and corms, respectively, and were independent of host susceptibility or resistance to $\mathrm{BXW} . \mathrm{H}_{2} \mathrm{O}_{2}$ production showed a biphasic transient pattern with an initial increase at 1-hour post Xcm inoculation (hpi), followed by a decline 3 to $6 \mathrm{hpi}$ and then a second increase by $12 \mathrm{hpi}$. Our findings point to organ-specific responses to $\mathrm{Xcm}$ infection in bananas. The corm, which doubles as a subterranean perennating organ and interface between mother plants and lateral shoots, was the most responsive organ in callose production, whereas the pseudostem was the most responsive organ in $\mathrm{H}_{2} \mathrm{O}_{2}$ production, suggesting the significance of these organs in banana response to $\mathrm{BXW}$.

Keywords: banana, callose, corm, fluorescence microscopy, hydrogen peroxide, Musa balbisiana, PAMP-triggered immunity, Xanthomonas campestris pv. musacearum, $\mathrm{Xcm}$-mediated defense 
Plant-pathogen interactions constitute an evolutionarily old "arms race" dynamic struggle between pathogens and plants in which the goal of the host plant is to remain healthy and productive (Anderson et al. 2010; Jones and Dangl 2006; Wang et al. 2021). In this struggle, plants defend themselves by recognizing pathogen-associated molecular patterns (PAMPs) such as bacterial flagellin via host-pattern recognition receptors (PRRs) that trigger a basal defense response called PAMP-triggered immunity (PTI) (Dodds and Rathjen 2010; Jones and Dangl 2006; Nicaise et al. 2009). PTI results in a myriad of defense responses such as oxidative burst, callose deposition, mitogen-activated protein kinase phosphorylation cascades, and transcriptome reprograming (Altenbach and Robatzek 2007; Moore et al. 2011; Schwessinger and Zipfel 2008). To overcome PTI response, pathogens secrete effectors that interfere with PTI (Dodds and Rathjen 2010; Jones and Dangl 2006). Plants also have hundreds of $R$ genes that mainly encode nucleotide-binding and leucine-rich repeat proteins that recognize and interact with the pathogens' effectors and activate a more robust defense response called effectortriggered immunity (ETI) (Jones and Dangl 2006; Dodds and Rathjen 2010). ETI response is often associated with localized cell death at the site of pathogen infection called the hypersensitive response that curtails pathogen progression (Jones and Dangl 2006; Nicaise et al. 2009).

During PTI, the production of reactive oxygen species such as hydrogen peroxide $\left(\mathrm{H}_{2} \mathrm{O}_{2}\right)$ is one of the early, rapid, transient, and measurable events (Bigeard et al. 2015; Torres et al. 2006). $\mathrm{H}_{2} \mathrm{O}_{2}$ performs multiple functions in plant defense against pathogens. For example, it is involved in direct antimicrobial activities at the sites of pathogen invasion; cell-wall reinforcement via lignification and oxidative cross-linking of cell-wall polymers; synthesis of phytoalexins; triggering programmed cell death during hypersensitive response, which restricts the spread of infection; signaling the induction and transduction of systemic acquired resistance in distal tissues; and activation of defense genes, and it is an essential component of the signal transduction cascade leading to numerous defense responses (Kuźniak and Urbanek 2000; O'Brien et al. 2012; Torres et al. 2006; Wang et al. 2019). The consequence of PTI prevention of microbial colonization by enhancing accumulation of callose (a 1,3- $\beta$-D-glucan polymer) between the cell wall and the plasma membrane and the plasmodesmata (Beckman et al. 1982; Cohen et al. 1990; Luna et al. 2011; Malinovsky et al. 2014; Underwood 2012). Callose is naturally involved in numerous routine plant biological processes (Nedukha 2015; Piršelová and Matušíková 2013). However, increased callose deposition in cell walls in response to pathogen infection prevents further microbial colonization (Beckman et al. 1982; Cohen et al. 1990; Kashyap et al. 2020; Malinovsky et al. 2014; Underwood 2012; Voigt 2014). By slowing pathogen invasion in the attacked tissue, callose deposition allows time for the induction of additional defense responses.

Studies of PTI in banana (Musa spp.) in response to bacterial pathogen Xanthomonas campestris pv. musacearum (Xcm) infection are very limited. The xylem-limited Xcm (also recently redesignated as Xanthomonas vascicola pv. musacearum, Xvm) (Studholme et al. 2020) is the cause of banana Xanthomonas wilt (BXW) disease, the most destructive disease of banana in East and Central Africa (ECA), where the crop supports the livelihoods of more than 70 million people (Abele et al. 2007; Dotto et al. 2018; FAOSTAT 2017; Nakato et al. 2018; Ocimati et al. 2019; Smith et al. 2008). Symptoms of BXW include progressive yellowing and wilting of leaves, premature and uneven ripening of fruits, and creamy yellowish bacterial oozes that appear 5 to 20 min after cutting diseased pseudostems (Smith et al. 2008; Tushemereirwe et al. 2004). These symptoms develop rapidly, and the infected plants wither and rot within 3 to 4 weeks under field conditions (Smith et al. 2008). Banana plants on the same mat (the mother plant, its lateral shoots, and underground corm) can all get infected because the $X \mathrm{~cm}$ bacteria have sufficient time to attack all the vital organs, including the underground corm (Ocimati et al. 2015; Ssekiwoko et al. 2006a).

All cultivated banana varieties grown in ECA are susceptible to BXW (Ndungo et al. 2006; Ssekiwoko et al. 2006b; Tripathi et al. 2008). The progenitor of cultivated bananas, the inedible wild Musa balbisiana, is the only source of resistance against BXW (Nakato et al. 2019; Ssekiwoko et al. 2006b, 2015). Currently, the molecular basis of resistance in M. balbisiana is not known. Considering the technical difficulties associated with introgression of $\mathrm{BXW}$ resistance from $M$. balbisiana into edible banana via conventional breeding, transgenic technologies are a more feasible tool to improve banana resistance against BXW (Tripathi et al. 2016, 2017). Alternatively, because $X \mathrm{~cm}$ bacteria show limited systemic movement even in susceptible genotypes (Ocimati et al. 2015), cultural methods such as single diseased stem removal (SDSR) (Kubiriba et al. 2014) could be effective in the management of BXW. In the SDSR method, diseased plants are observed early for symptoms and aseptically removed from the mats by cutting them off at the soil level, which curtails the bacteria from crossing the corm tissue to attack the lateral shoots (Blomme et al. 2017; Kubiriba et al. 2014). Indeed, in the early stages of flower-mediated $\mathrm{Xcm}$ infection, the bacteria are restricted to the upper parts of the true stem (Ssekiwoko et al. 2006a), indicating that some unknown mechanism hinders bacterial movement. Low bacterial loads in the corm together with latent $X \mathrm{~cm}$ infections were observed and assumed to be the cause of new BXW incidences in areas where the disease was previously controlled (Ocimati et al. 2013). Furthermore, Ocimati et al. (2015) showed incomplete systemic infection of $X \mathrm{~cm}$ in bananas, suggesting some PTI defenses against BXW. According to Tripathi et al. (2019), Xcm infection in banana could activate both PTI and ETI responses. Accordingly, our hypothesis is that $X \mathrm{~cm}$ infection triggers basal PTI responses whose spatial and temporal variability along the banana's anatomical structure accounts for initially restricting $X \mathrm{~cm}$ in upper organs.

In this study, we investigated how bananas respond to $X \mathrm{~cm}$ infection under screenhouse conditions with respect to callose deposition and $\mathrm{H}_{2} \mathrm{O}_{2}$ production as early measurable events of PTI. The understanding of these defense responses is vital for the production of BXW-resistant banana cultivars through either conventional breeding or genetic engineering technologies.

\section{MATERIALS AND METHODS}

\section{Plant materials}

This study was approved by the Uganda National Council for Science and Technology with the reference number NS107ES. Three banana genotypes, Pisang Awak (known in Uganda, and hereafter referred to, as Kayinja), Mbwazirume, and Musa balbisiana, were used in this study. Kayinja is a beer banana (triploid genotype ABB), Mbwazirume is a cooking "matooke" type of the East African Highland banana (EAHB, triploid AAA-EA), and $M$. balbisiana is a wild and inedible banana (diploid genotype BB). Kayinja and Mbwazirume were selected for their known susceptibility to BXW, whereas M. balbisiana is resistant to BXW (Nakato et al. 2019; Ssekiwoko et al. 2006b; Tripathi et al. 2008). Kayinja and Mbwazirume represent genotypes that are predominantly grown in two contrasting banana cropping systems of ECA: the less-managed Kayinja-based system common in the 
Democratic Republic of Congo, and the highly managed EAHBbased cropping system common in Uganda (Smith et al. 2008).

Healthy Kayinja, Mbwazirume, and M. balbisiana mother plants that were used to generate explants for tissue culture of the experimental plants were obtained from farmers' fields in Mbarara, southwestern Uganda. These mother plants were identified phenotypically using standard procedures at the $\mathrm{Na}$ tional Agricultural Research Laboratories (NARL) in Kawanda, Uganda. Voucher specimens for Kayinja, Mbwazirume, and M. balbisiana were deposited in the Makerere University Herbarium with the deposition numbers ASM001, ASM002, and ASM003, respectively. Plantlets of these genotypes were raised from the explants through standard tissue culture procedures at the Tissue Culture Laboratory of the NARL. The plantlets were weaned at $75 \%$ humidity in the humidity chamber for 1 month and hardened for 1 month before potting for establishment in a screenhouse. They were maintained in the screenhouse at the Banana Resource Centre at NARL under regular watering every 3 days at atmospheric temperatures between $18^{\circ} \mathrm{C}$ and $30^{\circ} \mathrm{C}$ for 2.5 months prior to inoculation with $\mathrm{Xcm}$.

\section{Isolation and preparation of $\mathrm{Xcm}$ inoculum}

The Xcm inoculum was isolated from a BXW-infected Kayinja plant from a banana plantation at Kifu Forest Reserve, Mukono district, Central Uganda. The presence of $\mathrm{Xcm}$ in the plant was confirmed using a lateral flow device (LFD) (DSMZ, Germany) according to the manufacturer's instructions. The pseudostem was cut into short pieces of $0.5 \mathrm{~m}$ and left for 15 to $40 \mathrm{~min}$ to allow the yellowish sap to ooze out of the cut surfaces. The bacterial ooze was carefully collected into $50-\mathrm{ml}$ falcon tubes, immediately transferred into a cool box maintained at $4^{\circ} \mathrm{C}$ and transported to the laboratory for analysis.

A portion of the fresh yellowish ooze was serially diluted 10-, 100-, 1,000-, 10,000-, and 100,000-fold with sterile distilled water, and the rest of the fresh ooze was stored at $4{ }^{\circ} \mathrm{C}$. Aliquots of $100 \mu \mathrm{l}$ of each of the dilutions were spread onto yeast extract peptone glucose agar (YPGA) containing 1\% (w/v) yeast extract, $1 \%(\mathrm{w} / \mathrm{v})$ peptone, $1 \%(\mathrm{w} / \mathrm{v})$ glucose, and $1.5 \%(\mathrm{w} / \mathrm{v})$ agar at $\mathrm{pH} 7.0$ and incubated for $48 \mathrm{~h}$ at $28^{\circ} \mathrm{C}$ as described by Mwangi et al. (2007). Characteristic Xcm colonies that appeared yellow, mucoid, and circular were sub-cultured further on a new YPGA medium to obtain pure $X \mathrm{~cm}$ colonies (Tripathi et al. 2007). To confirm whether the isolates were $X \mathrm{~cm}$, DNA was extracted from the pure colonies using the PureLink genomic DNA extraction kit (Thermo Fisher Scientific, U.S.A.) following the manufacturer's instructions, and PCR was run using $\mathrm{Xcm}$ specific GspDm-F2/GspDm-R3 primers as described by Adriko et al. (2012). The PCR product was assessed by agarose gel electrophoresis and thereafter cleaned using the ExoSAP-IT PCR product cleanup kit (Applied Biosystems) following the manufacturer's instructions. The cleaned PCR product was subjected to Sanger sequencing reactions using the BigDye Terminator v3.1 cycle sequencing kit (Applied Biosystems) at the DNA sequencing facility of the Department of Plant Sciences, Microbiology and Biotechnology, Makerere University, Uganda. The DNA sequences generated were compared with the existing DNA sequences in the National Center for Biotechnology Information (NCBI) GenBank using the Basic Local Alignment Search Tool (BLAST).

\section{Inoculation of banana plants with $\mathrm{Xcm}$}

Banana plants at 2.5 months old were used for this study in a completely randomized design. The bacterial ooze stored at $4{ }^{\circ} \mathrm{C}$ was retrieved after 5 days and diluted with sterile distilled water to $\mathrm{OD}_{600}=2.5\left(5 \times 10^{8} \mathrm{cells} / \mathrm{ml}\right)$. Experiments were performed in triplicate and repeated two times with similar results. Using 1-ml sterile syringes (BD Micro-Fine Plus, U.S.A.), 60 plants of each banana genotype were infiltrated with $200 \mu \mathrm{l}$ of the $X \mathrm{~cm}$ inoculum $\left(1 \times 10^{8}\right.$ cells $)$ on the dorsal side of leaf petioles as described by Ssekiwoko et al. (2006b). An additional 60 plants for each genotype were infiltrated with $200 \mu \mathrm{l}$ of sterile distilled water and used as controls. Twenty-four plants of each genotype from the inoculated and control groups were used to examine callose deposition in the banana tissues using both fluorescence microscopy and triple antibody sandwich enzymelinked immunosorbent assay (TAS-ELISA, hereafter referred to as ELISA). Additionally, 15 plants of each genotype from the inoculated and control groups were used for determination of $\mathrm{H}_{2} \mathrm{O}_{2}$ production by spectrophotometry and bright-field microscopy methods. The remaining 21 plants of each genotype from the inoculated and control groups were left for further observations of BXW disease development. These plants were observed daily for 56 days, and the time taken to show initial BXW symptoms and death of the entire plant were recorded. About $5 \mathrm{~cm}^{2}$ of leaf tissue from the $X \mathrm{~cm}$-inoculated and control groups were excised aseptically using sterile surgical blades and tested for $\mathrm{Xcm}$ at $0,1,2,7,14,28$, and 56 days postinoculation (dpi) by the LFD and PCR methods as described above.

\section{Sampling}

Destructive sampling was employed in the collection of samples from three $X \mathrm{~cm}$-inoculated plants and three controls at 0 , $1,3,6$, and $12 \mathrm{~h}$ postinoculation (hpi) for determination of $\mathrm{H}_{2} \mathrm{O}_{2}$ production by both spectrophotometry and bright-field microscopy methods. Similarly, tissue samples were collected at $0,1,2,7,14$, and 28 dpi from a different set of plants for determination of callose production by both fluorescence microscopy and ELISA methods. For fluorescence microscopy, samples were quickly excised using sterile surgical blades from pseudostems $(5 \mathrm{~cm}$ long, longitudinally from the top, where the pseudostem starts), roots $(5 \mathrm{~cm}$ long, up to five different roots), and corms ( $2 \mathrm{~cm}$ wide, sliced longitudinally from the center). Samples for bright-field microscopy were collected from the inoculated leaves $(6 \mathrm{~cm}$ long, from the leaf apex including the midrib), in addition to pseudostems and corms as described above. All the excised tissues were immediately immersed into formalin-acetic acid-alcohol (FAA) fixative solution, containing $50 \%(\mathrm{v} / \mathrm{v})$ ethanol, $5 \%(\mathrm{v} / \mathrm{v})$ acetic acid, $5 \%(\mathrm{v} / \mathrm{v})$ formalin, and $40 \%(\mathrm{v} / \mathrm{v})$ sterile distilled water to preserve, destain, and arrest any further metabolism in the tissues (Soukup and Tylová 2014). The tissues were kept in the fixative solution at room temperature in the laboratory until they were destained (48 to $72 \mathrm{~h}$ ).

For the ELISA and spectrophotometry methods, samples were quickly excised using sterile surgical blades from the inoculated leaves and the pseudostems $(6 \mathrm{~cm}$ long, longitudinally from where sampling for fluorescence microscopy and bright-field microscopy stopped). Sampling of roots (not considered for the spectrophotometry method) and corms was performed as stated above for fluorescence microscopy/bright-field microscopy. All the excised tissues were placed into well-labeled 50-ml falcon tubes and immediately immersed into liquid nitrogen. The samples were transported to the laboratory and stored at $-80^{\circ} \mathrm{C}$ until subsequent processing. Owing to the transient nature of $\mathrm{H}_{2} \mathrm{O}_{2}$ in plant tissues (Noctor et al. 2015), all tissues were processed within 8 to $24 \mathrm{~h}$ after collection. 


\section{Vacuum infiltration and tissue sectioning}

To further process the samples for fluorescence and bright-field microscopy, the tissues fixed in FAA were vacuum infiltrated for $10 \mathrm{~min}$ to remove intercellular air from the tissues as described by Soukup and Tylová (2014). Vacuum infiltration was done using a vacuum pump (model COM71/a, Coverco, Italy) connected to a glass desiccator. The vacuum-infiltrated tissues were recovered, and up to five sections each of $100-\mu \mathrm{m}$ thickness were made from each of the plant tissues using a sectioning knife (Dovo, Germany) and a hand-held microtome (MCT001, United Scientific Supplies, U.S.A.) as described by Soukup and Tylová (2014).

\section{Staining and microscopy}

The sections for determination of callose production were then stained in the dark for $2 \mathrm{~h}$ in freshly prepared $0.01 \%$ aniline blue fluorochrome prepared in $150 \mathrm{mM}$ of $\mathrm{K}_{2} \mathrm{HPO}_{4}$ (Schenk and Schikora 2015), whereas the sections for determination of $\mathrm{H}_{2} \mathrm{O}_{2}$ production were stained using the chromogen $3,3^{\prime}$ diaminobenzidine (DAB) as described by Daudi and O'Brien (2012), with a few modifications. The modifications to the DABstaining procedure included subjecting the tissues to $8 \mathrm{~min}$ instead of 5 min of vacuum infiltration with DAB; $2 \mathrm{~h}$ instead of $4 \mathrm{~h}$ of shaking at $100 \mathrm{rpm}$; and $300 \mu \mathrm{l}$ instead of $200 \mu \mathrm{l}$ of DAB reagent. These volumes were adjusted to enable better visibility of the DAB stain under the microscope. The sections were then rinsed using sterile water until the rinsing water was colorless. The clean tissue sections were then mounted on glass slides in a droplet of sterile water. The aniline blue-stained callose and DAB-stained $\mathrm{H}_{2} \mathrm{O}_{2}$ were visualized through fluorescence microscopy (using the DAPI filter at $365 \mathrm{~nm}$ excitation and $450 \mathrm{~nm}$ emission) and bright-field microscopy, respectively. All microscopic observations were done under an AxioScope A1 microscope (Carl-Zeiss, Oberkochen, Germany). Image acquisition, processing, and management were conducted using ZEN 2.3 SP1 imaging software (Carl-Zeiss). Up to four images were captured for each organ at $1,300 \times 1,030$ resolution in monochrome and color formats. All images were captured at $100 \times$ magnification and then converted to jpeg format for callose quantification and $\mathrm{H}_{2} \mathrm{O}_{2}$ localization.

\section{Quantitative determination of callose by the Callosecounter software}

To provide a quantitative estimate of callose observed under the microscope, the images obtained from fluorescence microscopy were all first converted to 8-bit and saved as TIFF before batch processing for callose quantification. The multiple rotational morphological processing program, set up as a Callosecounter plugin for Icy software (Image Analysis Hub, Institut Pasteur, Paris, France), was used for callose quantification of the TIFF images as described by Kohari et al. (2016). The callose particles observed under fluorescence microscope were read and interpreted as callose particle counts per square millimeter (counts $\mathrm{mm}^{-2}$ ) of the tissue sections.

\section{ELISA and quantification of callose}

The plant samples stored at $-80^{\circ} \mathrm{C}$ were retrieved in 2 months, and extraction of callose from the tissues was performed according to Kohler et al. (2000) and Khaledi et al. (2018). The callose extracts were stored at $-20^{\circ} \mathrm{C}$ until further analysis. TASELISA was used to quantify $\mathrm{Xcm}$-induced callose deposition in the banana organs contained in the extracts (Anderson and McNellis 1998; Engvall and Perlmann 1971; Hosseini et al. 2018;
Van Weemen and Schuurs 1971). The ELISA plates (SARSTEDT AG \& Co. KG, Germany) were prepared by coating wells with the primary coating antibody (1-3- $\beta$-glucan-directed mouse IgG, Biosupplies Australia). To each well, $100 \mu \mathrm{l}$ of the coating antibody was added, and the plates were covered with aluminum foil and incubated overnight at $4{ }^{\circ} \mathrm{C}$. The plates were further processed by standard ELISA blotting and washing procedures (Hosseini et al. 2018) prior to the addition of test samples.

One-hundred microliters of the callose extracts were added to the designated wells of the plates in triplicate. Similarly, $100 \mu 1$ of laminarin standard (Biosupplies Australia) at concentrations of $90,70,50,30,10,0.9,0.7$, and $0.5 \mathrm{mg} / \mathrm{ml}$ was also added to the designated wells of the plates in quadruplet and used as a standard for callose quantification (Chen and Kim 2009; Nelson and Lewis 1974; Rioux et al. 2007; Zhang et al. 2015; Zvyagintseva et al. 1999). Blanks of $100 \mu \mathrm{l}$ (prepared by mixing $1 \mathrm{M} \mathrm{NaOH}$ and blocking buffer at a ratio of 1:2) were also added to the designated wells in quadruplet. The plates were covered and incubated overnight at $4^{\circ} \mathrm{C}$. The plates were allowed to warm to room temperature; blotting and washing of the plates were done as described above. About $100 \mu \mathrm{l}$ of diluted secondary antibody (1-3- $\beta$-glucan-directed Mouse IgG, Biosupplies Australia) was added to the wells. The plates were covered with aluminum foil and incubated for $4 \mathrm{~h}$ at $37^{\circ} \mathrm{C}$, after which they were allowed to cool to room temperature with blotting and washing procedures repeated as described above. About $100 \mu \mathrm{l}$ of the diluted detection (conjugated) antibody (anti-Mouse IgG-Alkaline phosphatase, Lasec International, South Africa) was added to the wells (Engvall and Perlmann 1971; Hosseini et al. 2018). The plates were covered with aluminum foil and incubated overnight at $4^{\circ} \mathrm{C}$. The plates were then allowed to warm to room temperature; blotting and washing of the plates were done as described above.

To quantify callose in the extracts by spectrophotometry, $100 \mu \mathrm{l}$ of freshly prepared para-nitrophenyl phosphate (Lasec International) at a concentration of $1 \mathrm{mg} / \mathrm{ml}$ was added to the wells and left to incubate at room temperature (Reen 1994). After $30 \mathrm{~min}$, the reactions were terminated by addition of $100 \mu \mathrm{l}$ of freshly prepared $3 \mathrm{M} \mathrm{NaOH}$ (Reen 1994). The plates were transferred to an iMark Microplate Reader (BIO-RAD, Japan) and shaken at medium speed for $1 \mathrm{~min}$, and absorbances were read at $405 \mathrm{~nm}$ (Reen 1994). The absorbance readings obtained from the laminarin standard (y-axis) and the known laminarin concentrations (x-axis) were used to plot a standard curve. A simple linear regression of laminarin absorbance at $405 \mathrm{~nm}$ against $\log _{10}$ of laminarin concentration $(\mu \mathrm{g} / \mathrm{ml})$ was performed to obtain the standard curve, $\mathrm{Y}=\beta_{1} \mathrm{X}+\beta_{0}\left(\mathrm{Y}=\right.$ callose absorbance at $405 \mathrm{~nm}, \beta_{1}=$ slope of the regression line, $X=\log _{10}$ [callose concentration in $\mu \mathrm{g} / \mathrm{ml}]$, and $\beta_{0}=$ Y-intercept). Callose absorbance and concentrations were recorded as laminarin equivalents.

\section{Extraction and quantification of $\mathrm{H}_{2} \mathrm{O}_{2}$}

Hydrogen peroxide was extracted from tissues using a method described by Patterson et al. (1984). The amount of $\mathrm{H}_{2} \mathrm{O}_{2}$ in each of the extracts from the tissues was determined according to Zhou et al. (2006), with absorbance of extracts measured using a spectrophotometer (model Nano Drop One ${ }^{\mathrm{C}} \mathrm{U}$.V/Vis, Thermo Fisher Scientific) at $240 \mathrm{~nm}$. To determine the actual concentration of $\mathrm{H}_{2} \mathrm{O}_{2}$ in the plant extracts, a standard $\mathrm{H}_{2} \mathrm{O}_{2}$ curve was produced. Aliquots of $2.5 \mathrm{ml}$ of distilled water were dispensed into five 10-ml falcon tubes. A stock solution of $\mathrm{H}_{2} \mathrm{O}_{2}$ at $50 \%$ (w/v) was used to prepare serial dilutions. An aliquot of $2.5 \mathrm{ml}$ of $50 \%$ $\mathrm{H}_{2} \mathrm{O}_{2}$ was dispensed into the first tube containing $2.5 \mathrm{ml}$ of distilled water and mixed well to make a uniform solution of $\mathrm{H}_{2} \mathrm{O}_{2}$. The stock solution was then serially diluted each time by trans- 
ferring $2.5 \mathrm{ml}$ of the solution from the previous dilution into the subsequent five falcon tubes each containing $2.5 \mathrm{ml}$ of distilled water. The amount of $\mathrm{H}_{2} \mathrm{O}_{2}$ in each of the five serial dilutions was determined against distilled water as a blank, and their respective absorbance was recorded by a spectrophotometer at $240 \mathrm{~nm}$. Absorbance values of the serially diluted $\mathrm{H}_{2} \mathrm{O}_{2}$ were plotted against their molar concentrations to generate a standard curve describing the Lambert-Beer relationship between absorbance and molar concentration (M) (Beer 1852; Lambert 1760), which was used to calculate the amount of $\mathrm{H}_{2} \mathrm{O}_{2}$ in the aliquots of the filtrate extracted from plant tissues.

\section{Data analysis}

All data analysis was conducted in $\mathrm{R}$ statistical package version 3.6.3 (R Core Team 2020). The Shapiro-Wilk normality test and Levene's $F$ test were used to check for normality of data distribution and homogeneity of variances $(\alpha=0.05)$, respectively. Where normality of distribution and/or homogeneity of variances was violated, the data were log transformed before analysis of variance (ANOVA) was performed, and where log transformations did not solve these violations, Welch's ANOVA (assuming unequal variances) was used instead. Data that were normally distributed and homoscedastic were analyzed using ANOVA at $\alpha=0.05$ followed by Tukey's post hoc test, whereas data that violated homogeneity of variance were analyzed using Welch's ANOVA followed by the Games-Howell post hoc test (Games and Howell 1976) to show significant differences between the group means. Additionally, the fluorescence microscopy and ELISA data on callose were analyzed through factorial ANOVA to investigate the effect sizes of treatment, genotype, organ, and time as well as their interaction on the total variance in callose production. Actual values were used for data presentation using Excel tables and graphs (GraphPad Prism software version 8.0.2, GraphPad Software, U.S.A.).

\section{RESULTS}

\section{Susceptibility of host plants to Xcm and development of BXW}

The identity of $\mathrm{Xcm}$ isolate collected from the field and used in this study was confirmed by PCR showing the expected amplicon size of approximately 265 base pairs (data not shown). The nucleotide sequence of the amplicon when compared with the DNA sequences in the NCBI database showed $100 \%$ identity to Xanthomonas campestris pv. musacearum NCPPB 4379 (accession number CP034655.1).

On inoculation with the $\mathrm{Xcm}$ isolate, the plants developed wilting symptoms at varying rates, with Kayinja plants showing earlier wilting symptoms, followed by Mbwazirume and M. balbisiana (Fig. 1). The three banana genotypes showed statistically significant differences in the mean number of days postinoculation to first appearance of symptoms and death of entire plants (Welch's ANOVA, $F_{(4,18.28)}=3045, P<0.001, n=21$ ) (Fig. $1 \mathrm{M}$ ). Symptoms were first characterized by necrosis around the site of inoculation, followed by drooping of the inoculated leaves, then widespread chlorosis and necrosis of the inoculated leaves that spread to all leaves and the pseudostem, and finally,
Control

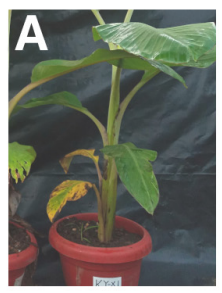

Mbwazirume

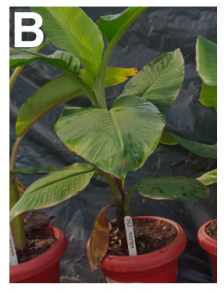

M. balbisiana

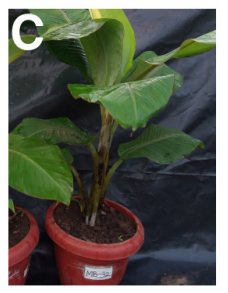

$14 \mathrm{dpi}$
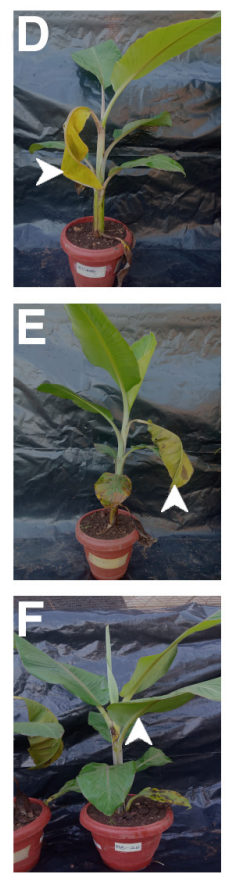

\section{$28 \mathrm{dpi}$}
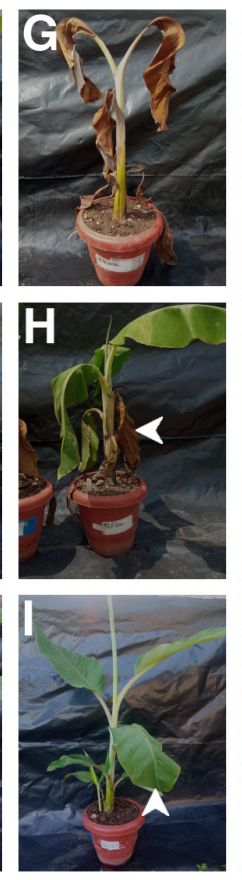

$56 \mathrm{dpi}$
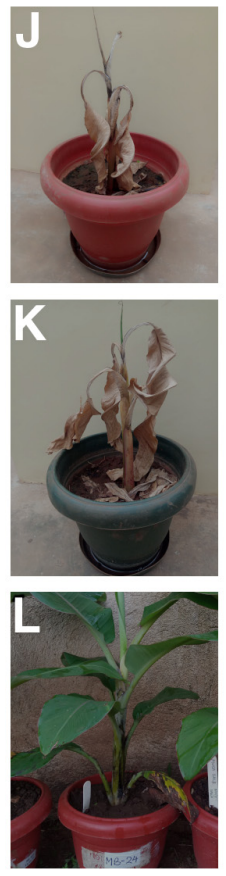
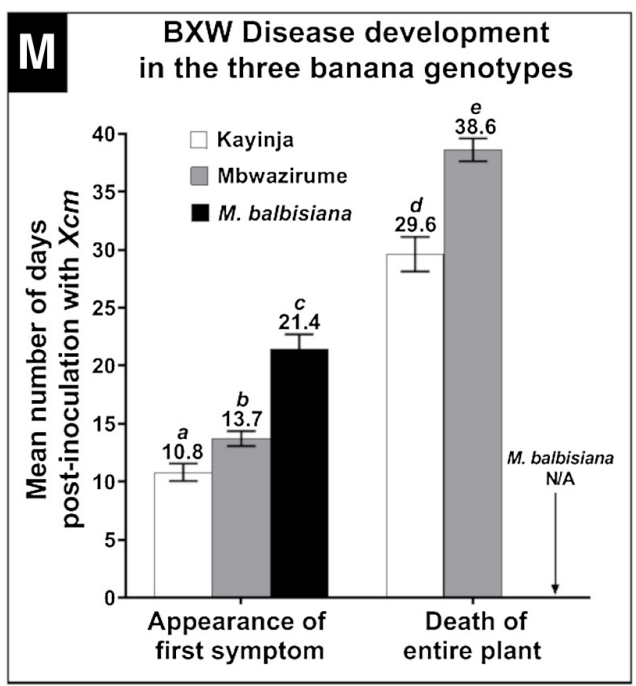

FIGURE 1

Banana Xanthomonas wilt (BXW) disease development in the three banana genotypes. Symptomless plants of non-inoculated Kayinja (A), Mbwazirume (B), and Musa balbisiana (C) and development of BXW disease symptoms (white arrowheads) in Kayinja (D, G, J), Mbwazirume $(\mathbf{E}, \mathbf{H}, \mathbf{K})$, and $M$. balbisiana $(\mathbf{F}, \mathbf{I}, \mathbf{L})$ at 14, 28, and 56 days postinoculation (dpi) with Xanthomonas campestris pv. musacearum $(\mathrm{Xcm})$. Localized hypersensitive response was observed in the inoculated leaf of $M$. balbisiana plants by $14 \mathrm{dpi}(\mathrm{F})$ and remained symptomless and healthy by $56 \mathrm{dpi}(\mathrm{L})$ compared with Kayinja (top row) and Mbwazirume (middle row), which displayed systemic wilting or yellowing at $14 \mathrm{dpi}$ and completely dried by $56 \mathrm{dpi}$. Experiments were performed in triplicate and repeated two times with similar results. The mean number of days postinoculation to first appearance of BXW symptoms and death of entire plants in response to $X \mathrm{~cm}$ inoculation in the three banana genotypes (Welch's ANOVA; $F_{(4,86)}=2,537, n=21, P<0.001$ ) (M). Different letters indicate significant differences (ANOVA; Welch's ANOVA; $P \leq 0.05$ ). 
death of the entire plant (Fig. 1). All inoculated Kayinja and Mbwazirume plants experienced drooping of the $\mathrm{Xcm}$-inoculated leaves as early as 11 and 14 dpi, respectively (Fig. 1M). Further systemic spread of BXW disease symptoms and death of the entire plants for Kayinja and Mbwazirume were observed at 30 and 39 dpi, respectively (Fig. 1M). On the contrary, only 4 out of $21 \mathrm{M}$. balbisiana plants experienced drooping of the inoculated leaves by $21 \mathrm{dpi}$, with no systemic disease progression observed; later, the four plants recovered and were asymptomatic, like the control plants (Fig. 1). At 7 dpi, the leaves of the $X \mathrm{~cm}$-inoculated Kayinja and Mbwazirume plants tested positive for $X \mathrm{~cm}$ using LFDs and PCR, and at $14 \mathrm{dpi}$, the leaves of M. balbisiana tested positive for $\mathrm{Xcm}$. However, at the termination of the experiment, $56 \mathrm{dpi}, M$. balbisiana tested negative for $X \mathrm{~cm}$, similar to the control plants (Table 1).

\section{Variations in callose production due to $\mathrm{Xcm}$ inoculation}

For callose quantification by fluorescence microscopy, the method developed by Kohari et al. (2016) was used, whereas the standard curve of laminarin absorbance at $405 \mathrm{~nm}$ against known laminarin concentrations $(\mathrm{Y}=0.5079 * \mathrm{X}-0.04534$, $\left.r=0.9988, r^{2}=0.9975, F_{(1,7)}=2845, P<0.001\right)$ was used to compute the unknown callose concentrations from the obtained callose absorbance at $405 \mathrm{~nm}$ (Supplementary Fig. S1A).

Treatment of the three banana genotypes with $\mathrm{Xcm}$ revealed significant variation in callose production between the $\mathrm{Xcm}$ inoculated plants and the control plants by both fluorescence microscopy (ANOVA, $F_{(1,286)}=9.43, P=0.0023$ ) and ELISA detection (Welch's ANOVA, $F_{(1,1062)}=25.75, P<0.001$ ) (Table 2, Fig. 2, Supplementary Fig. S2A and B). Although there was also a general increase in callose in the controls, the amounts were consistently lower than those in the inoculated plants (Table 2, Fig. 2, Supplementary Fig. S2A and B). Additionally, inoculation of the plants with $X \mathrm{~cm}$ accounted for $3.2 \%$ of total variance in callose production as detected by fluorescence microscopy (factorial ANOVA, $\left.F_{(1,216)}=1024.11, P<0.001\right)$ or $0.7 \%$ of the total variance as detected by ELISA (factorial ANOVA, $F_{(1,1046)}$ $=2228.38, P<0.001)($ Table 3$)$.

\section{Variations in callose production between the three banana genotypes}

Interestingly, this study revealed significant variation in callose production between the three banana genotypes when analyzed by fluorescence microscopy $\left(\right.$ ANOVA, $F_{(2,285)}=3.049, P=$

\section{TABLE 1}

Presence $(+)$ or absence (-) of Xanthomonas campestris pv. musacearum $(\mathrm{Xcm})$ in the leaves of the $\mathrm{Xcm}$-inoculated and control plants as detected by lateral flow devices and $\mathrm{PCR}^{\mathrm{z}}$

\begin{tabular}{lcccc}
\hline Time (dpi) & Kayinja & Mbwazirume & Musa balbisiana & Controls \\
\hline 0 & - & - & - & - \\
1 & - & - & - & - \\
2 & - & - & - & - \\
7 & + & + & - & - \\
14 & + & + & + & - \\
28 & + & + & + & - \\
35 & na & na & + & - \\
42 & na & na & + & - \\
49 & na & na & + & - \\
56 & na & na & - & - \\
\hline
\end{tabular}

$\mathrm{z}$ The experimental plants had completely wilted, and testing of the plants by lateral flow device and PCR was not performed. na = not applicable.
0.049 ) but not by the ELISA detection method (ANOVA, $F_{(2,1175)}$ $=1.30, \mathrm{P}=0.273$ ) (Table 2, Supplementary Fig. S2A and B). The trend of callose production in the three genotypes was consistent when fluorescence microscopy was used for callose quantification, consistently showing the highest callose production in M. balbisiana, followed by Mbwazirume and, lastly, Kayinja (Fig. 2). However, partial eta squared $\left(\eta^{2}\right)$ showed that genotype only accounted for $2.1 \%$ and $0.2 \%$ (effect size) of the total variance in the observed callose production by fluorescence microscopy and ELISA, respectively (factorial ANOVA, $P<0.001$ ) (Table 3).
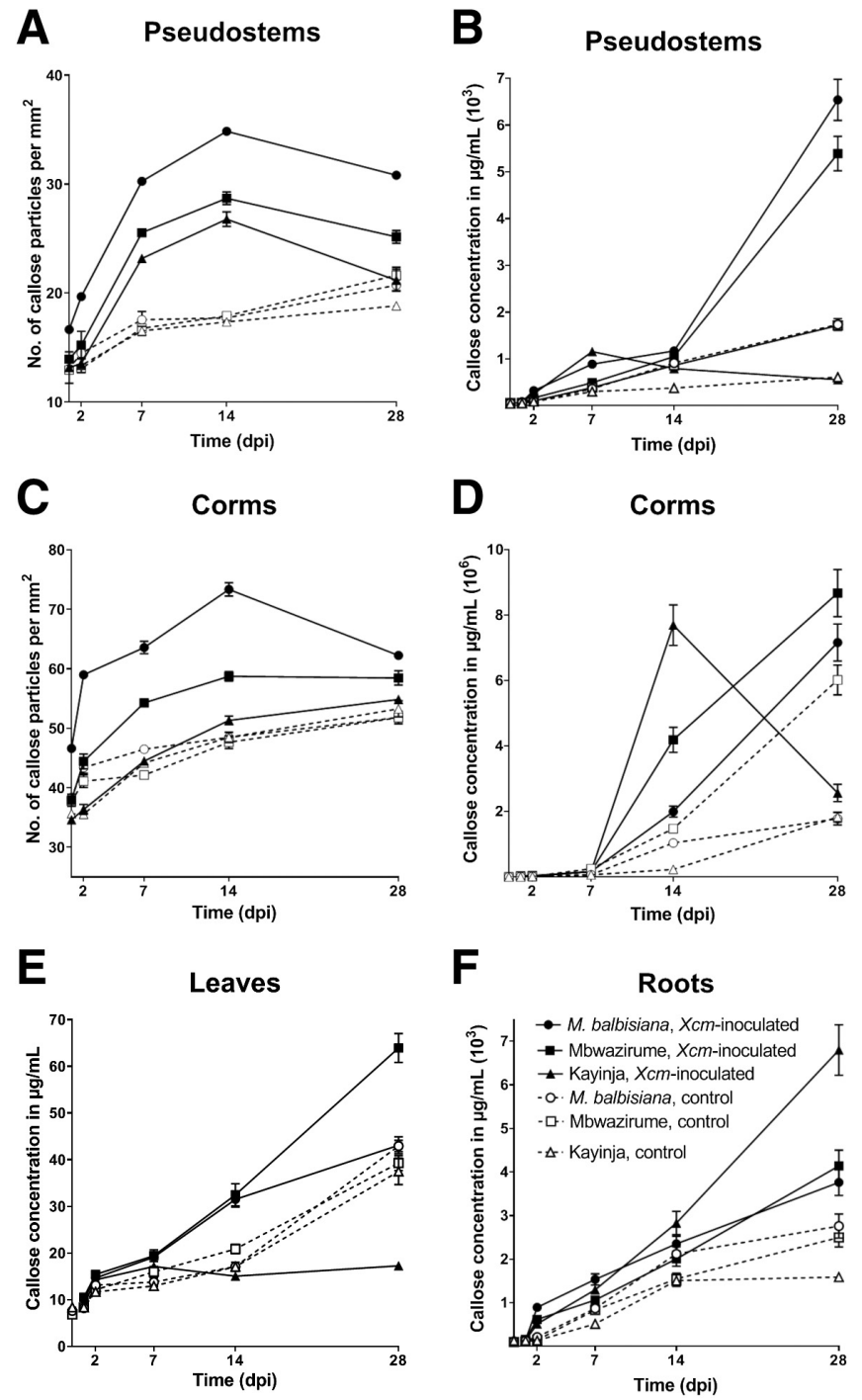

FIGURE 2

Callose production in pseudostems (A and B), corms (C and D), leaves $(\mathbf{E})$, and roots $(\mathbf{F})$ of Xanthomonas campestris pv. musacearum $(X \mathrm{~cm})$-inoculated and control banana genotypes at $0,2,7,14$, and 28 days postinoculation (dpi) as assessed by fluorescence microscopy (A and C) and ELISA (B, D, E, and F). Significant variability $(P<0.001)$ in callose production in $X \mathrm{~cm}$-inoculated plants was observed between the genotypes (fluorescence microscopy), treatments, organs, and time (dpi) (Welch's ANOVA, $P<0.05$ ), whereas no significant difference was observed between the genotypes as assessed by the ELISA method $(P>0.05$; Table 2). Experiments were performed in triplicate and repeated two times, generating consistent results. 


\section{Variations in callose production between organs of different banana genotypes}

Callose deposits were consistently observed as densely packed white fluorescing particles in the corm compared with few particles in the pseudostem (Fig. 3). Surprisingly, using the ELISA method, callose was also detected in the roots, even though no fluorescing callose particles had been observed in the roots by the fluorescence microscopy method (Table 2, Figs. 2 and 3, Supplementary Fig. S2). Therefore, for further analysis of fluorescence microscopy data, the root tissues were not considered. This study revealed significant differences in callose deposition in the banana organs by both fluorescence microscopy (Welch's ANOVA, $\left.F_{(1,242.56)}=853.07, P<0.001\right)$ and the ELISA detection method (Welch's ANOVA, $F_{(3.542 .52)}=1636.80, P<0.001$ ), with the corm producing 2- to 4-fold more callose deposition than roots, pseudostems, and leaves (Table 2, Supplementary Fig. S2A and B). Quite interestingly, organs accounted for $74.9 \%$ of the total variance in callose production as observed by fluorescence microscopy (factorial ANOVA, $F_{(1,216)}=24027.78$,
$P<2.2 \times 10^{-16}$; Table 3 ). The same observations were made using ELISA detection, in which up to $79.3 \%$ of total variance in callose production was accounted for by the organs (factorial ANOVA, $F_{(3,1046)}=89779.53, P<2.2 \times 10^{-16}$, Table 3$)$.

\section{Effect of $X \mathrm{~cm}$ inoculation over time on callose production}

This study showed that callose production was significantly different across the different time points when assessed by fluorescence microscopy (Welch's ANOVA, $F_{(5,131.23)}=8.83$, $P<0.001)$. Significant differences in callose production across the sampling time points were also obtained when the ELISA method was used for callose quantification (Welch's ANOVA, $\left.F_{(5,506.58)}=55.62, P<0.001\right)$ (Table 2). Interestingly, corms and pseudostems in all genotypes showed presence of constitutive callose at 0 dpi prior to $\mathrm{Xcm}$ inoculation (Table 2, Fig. 2, Supplementary Fig. S2A and B). Observations at 0 dpi by the fluorescence microscopy method indicated the presence of constitutive callose in the pseudostems and corms in the range of 12.20 to 13.22 and 35.91 to 38.31 particles $\mathrm{mm}^{-2}$, respectively (Fig. 2A and C,

TABLE 2

Quantification of callose production in the three banana genotypes inoculated with Xanthomonas campestris pv. musacearum (Xcm) ${ }^{\mathrm{Z}}$

\begin{tabular}{|c|c|c|c|c|c|c|c|c|c|c|c|c|}
\hline \multirow[b]{2}{*}{ Factors } & \multicolumn{6}{|c|}{ Callose quantification by fluorescence microscopy (particles per $\mathrm{mm}^{2}$ ) } & \multicolumn{6}{|c|}{ Callose quantification by ELISA ( $\mu \mathrm{g} / \mathrm{ml})$} \\
\hline & $\mathrm{Df}_{1}, \mathrm{Df}_{2}$ & $F$ & $P$ & Factor levels & $N$ & $\overline{\mathrm{X}} \pm \mathrm{SEM}$ & $\mathrm{Df}_{1}, \mathrm{Df}_{2}$ & $F$ & $P$ & Factor levels & $N$ & $\overline{\mathrm{X}} \pm \mathrm{SEM}$ \\
\hline \multirow[t]{3}{*}{ Genotype } & 2,285 & 3.049 & 0.049 & Kayinja & 96 & $29.74 \pm 1.46 \mathrm{a}$ & 2,1175 & 1.30 & 0.273 & Kayinja & 403 & $2.64 \pm 0.07$ \\
\hline & & & & Mbwazirume & 96 & $31.88 \pm 1.59 \mathrm{ab}$ & & & & Mbwazirume & 383 & $2.81 \pm 0.08$ \\
\hline & & & & Musa balbisiana & 96 & $35.42 \pm 1.85 \mathrm{~b}$ & & & & M. balbisiana & 392 & $2.77 \pm 0.08$ \\
\hline \multirow[t]{2}{*}{ Treatment } & 1,286 & 9.43 & 0.0023 & Control & 144 & $29.46 \pm 1.22$ & 1,1062 & 25.75 & $\overline{\mathrm{T}}<0.001$ & Control & 643 & $2.53 \pm 0.06$ \\
\hline & & & & $X c m$ & 144 & $35.24 \pm 1.44$ & & & & $X \mathrm{~cm}$ & 535 & $2.99 \pm 0.07$ \\
\hline \multirow[t]{4}{*}{ Organ } & $1,242.56$ & 853.07 & $\mathrm{~T}^{\overline{\mathrm{T}}}<0.001$ & Pseudostems & 144 & $18.34 \pm 0.51$ & $3,542.52$ & $1,636.80$ & ${ }^{\overline{\mathrm{T}}}<0.001$ & Pseudostems & 300 & $2.42 \pm 0.04 \mathrm{~b}$ \\
\hline & & & & Corms & 144 & $46.35 \pm 0.81$ & & & & Corms & 262 & $5.06 \pm 0.07 \mathrm{~d}$ \\
\hline & & & & Leaves & N/A & N/A & & & & Leaves & 330 & $1.16 \pm 0.01 \mathrm{a}$ \\
\hline & & & & Roots & N/A & N/A & & & & Roots & 286 & $2.76 \pm 0.03 c$ \\
\hline \multirow[t]{6}{*}{ Time (dpi) } & $5,131.23$ & 8.83 & ${ }^{\overline{\mathrm{T}}}<0.001$ & 0 & 48 & $24.92 \pm 1.80 \mathrm{a}$ & $5,506.58$ & 55.62 & $\overline{\mathrm{T}}<0.001$ & 0 & 111 & $1.78 \pm 0.08 \mathrm{a}$ \\
\hline & & & & 1 & 48 & $26.15 \pm 1.85 \mathrm{a}$ & & & & 1 & 243 & $2.03 \pm 0.07 \mathrm{ab}$ \\
\hline & & & & 2 & 48 & $29.10 \pm 2.24 \mathrm{ab}$ & & & & 2 & 235 & $2.40 \pm 0.08 \mathrm{~b}$ \\
\hline & & & & 7 & 48 & $35.41 \pm 2.22 b c$ & & & & 7 & 204 & $2.95 \pm 0.10 \mathrm{c}$ \\
\hline & & & & 14 & 48 & $39.27 \pm 2.54 \mathrm{c}$ & & & & 14 & 197 & $3.42 \pm 0.13 \mathrm{~d}$ \\
\hline & & & & 28 & 48 & $39.23 \pm 2.43 c$ & & & & 28 & 188 & $3.70 \pm 0.14 \mathrm{~d}$ \\
\hline
\end{tabular}

${ }^{\mathrm{z}}$ Means at each factor level followed by different letters indicate significant differences (ANOVA or Welch's ANOVA, $P \leq 0.05$ ). The symbol ${ }^{\bar{\top}}$ indicates Welch's ANOVA. For data that violated Levene's test for homogeneity of variance, Welch's ANOVA was used. Data are shown as mean \pm standard error of the mean. Experiments were performed in triplicate and repeated two times with similar results.

TABLE 3

Main and interaction effect sizes of the different independent factors on callose production in the three banana genotypes inoculated with Xanthomonas campestris pv. musacearum (Xcm)

\begin{tabular}{|c|c|c|c|c|c|c|c|c|}
\hline \multirow[b]{2}{*}{ Factors } & \multicolumn{4}{|c|}{ Callose detection by fluorescence microscopy } & \multicolumn{4}{|c|}{ Callose detection by ELISA method } \\
\hline & $\mathrm{Df}_{1}$ & $F$ & $P$ & Partial eta squared $\left(\eta^{2} \mathrm{p}\right)$ & $\mathrm{Df}_{1}$ & $F$ & $P$ & Partial eta squared $\left(\eta^{2} p\right)$ \\
\hline Genotype (G) & 2 & 336.02 & $<0.001$ & 0.021 & 2 & 300.85 & $<0.001$ & 0.002 \\
\hline $\operatorname{Organ}(\mathrm{O})$ & 1 & $24,027.78$ & $<0.001$ & 0.749 & 3 & $89,779.5$ & $<0.001$ & 0.793 \\
\hline Time (Ti) & 5 & 853.44 & $<0.001$ & 0.133 & 5 & $9,363.88$ & $<0.001$ & 0.138 \\
\hline Treatment (Tr) & 1 & $1,024.11$ & $<0.001$ & 0.032 & 1 & $2,228.38$ & $<0.001$ & 0.007 \\
\hline $\mathrm{G} \times \mathrm{O}$ & 2 & 70.21 & $<0.001$ & 0.004 & 6 & 107.17 & $<0.001$ & 0.002 \\
\hline $\mathrm{G} \times \mathrm{Ti}$ & 10 & 17.31 & $<0.001$ & 0.005 & 10 & 39.33 & $<0.001$ & 0.001 \\
\hline $\mathrm{O} \times \mathrm{Ti}$ & 5 & 52.69 & $<0.001$ & 0.008 & 15 & $1,016.87$ & $<0.001$ & 0.045 \\
\hline $\mathrm{G} \times \mathrm{Tr}$ & 2 & 188.36 & $<0.001$ & 0.012 & 2 & 11.33 & $<0.001$ & 0 \\
\hline $\mathrm{O} \times \mathrm{Ti}$ & 1 & 9.63 & 0.022 & 0 & 3 & 213.12 & $<0.001$ & 0.002 \\
\hline $\mathrm{Ti} \times \mathrm{Tr}$ & 5 & 113.18 & $<0.001$ & 0.018 & 4 & 26.71 & $<0.001$ & 0 \\
\hline $\mathrm{G} \times \mathrm{O} \times \mathrm{Ti}$ & 10 & 9.84 & $<0.001$ & 0.003 & 30 & 20.82 & $<0.001$ & 0.002 \\
\hline $\mathrm{G} \times \mathrm{O} \times \mathrm{Tr}$ & 2 & 30.54 & $<0.001$ & 0.002 & 6 & 27.42 & $<0.001$ & 0 \\
\hline $\mathrm{G} \times \mathrm{Ti} \times \mathrm{Tr}$ & 10 & 12.31 & $<0.001$ & 0.004 & 8 & 32.2 & $<0.001$ & 0.001 \\
\hline $\mathrm{O} \times \mathrm{Ti} \times \mathrm{Tr}$ & 5 & 2.86 & 0.016 & 0 & 12 & 50.21 & $<0.001$ & 0.002 \\
\hline $\mathrm{G} \times \mathrm{O} \times \mathrm{Ti} \times \mathrm{Tr}$ & 10 & 5.01 & $<0.001$ & 0.002 & 24 & 29.16 & $<0.001$ & 0.002 \\
\hline Residuals $\left(\mathrm{Df}_{2}\right)$ & 216 & & & 0.007 & 1,046 & & & 0.003 \\
\hline
\end{tabular}


Supplementary Fig. S2A). The ELISA method indicated constitutive callose production in the leaves, pseudostems, corms, and roots in the range of 6.87 to $2132 \mu \mathrm{g} / \mathrm{ml}$ (Fig. $2 \mathrm{~B}$ and D to F, Supplementary Fig. S2B). On Xcm inoculation, callose production increased significantly $(P<0.001)$, rapidly reaching a maximum of 17.36 to 34.85 and 47.64 to 73.31 particles $\mathrm{mm}^{-2}$ at $14 \mathrm{dpi}$ in the pseudostems and corms, respectively, as analyzed by fluorescence microscopy (Fig. 2A and C).

On the contrary, the ELISA data showed a slow increase in callose in the pseudostems as compared with the corms to a maximum of 555.86 to $6,540.30$ and $1,778,609.36$ to $8,673,866.36$ $\mu \mathrm{g} / \mathrm{ml}$ at $28 \mathrm{dpi}$ for the pseudostems and corms, respectively (Fig. 2B and D). The leaves and roots analyzed by ELISA showed a similar trend to that of the pseudostems and corms (Fig. 2E and F). In all cases, an initial increase in callose lasted for and peaked at 7 to $14 \mathrm{dpi}$, followed by a negligible increase observed at $28 \mathrm{dpi}$ (Fig. 2A to F).

Callose production attained statistically significant levels at 7 dpi as compared with 0 and 1 dpi but not 2 dpi and further increased, although not significantly, at $14 \mathrm{dpi}$ and remained not significantly different until 28 dpi (Table 1, Supplementary Fig. S2A). According to ELISA, there was significant callose production at $2 \mathrm{dpi}$ as compared with $0 \mathrm{dpi}$, which increased significantly at 7 and $14 \mathrm{dpi}$ and remained unchanged up to $28 \mathrm{dpi}$ (Table 2, Supplementary Fig. S2B). ELISA showed a slow increase in callose from 0 to $14 \mathrm{dpi}$, followed by a sharp increase up to $28 \mathrm{dpi}$, an exception being the slow decline in the pseudostems (7 to $28 \mathrm{dpi}$ ) and a sharp decline in the corms (14 to 28 dpi) of Kayinja (Fig. 2B and D).

Interestingly, partial eta squared $\left(\eta^{2}\right)$ showed that time accounted for 13.3 and $13.8 \%$ of total variance in callose produc- tion as detected by fluorescence microscopy (factorial ANOVA, $F_{(5,216)}=853.44, P<0.001$ ) and ELISA (factorial ANOVA, $\left.F_{(5,216)}=9363.88, P<0.001\right)$, respectively (Table 3$)$.

\section{Interaction effects between treatment, genotype, organ, and time on callose production}

The interactions between all experimental variables showed statistically significant effects on callose production by fluorescence microscopy $\left(P=1.5 \times 10^{-6}\right)$ and ELISA $\left(P=2.2 \times 10^{-16}\right)$ (Table 4). However, certain interactions contributed no variance $(0.0 \%)$ in callose production, such as organ $\times$ treatment, organ $\times$ time $\times$ treatment (fluorescence microscopy), and genotype $\times$ treatment, time $\times$ treatment, genotype $\times$ organ $\times$ treatment (ELISA). Organ $\times$ time yielded the highest interaction effect by contributing to $4.5 \%$ of the total variance in callose detection by ELISA. Additionally, organ and time, which had the highest single-factor effects of 79.3 and $13.8 \%$, respectively, had a $4.5 \%$ effect due to their interaction (factorial ANOVA, Table 4). In contrast, fluorescence microscopy data showed that the time $\times$ treatment interaction contributed the highest interaction effect of $1.8 \%$ of the total variance in callose production (factorial ANOVA, Table 4).

\section{Histolocalization of $\mathrm{H}_{2} \mathrm{O}_{2}$ in $\mathrm{Xcm}$-inoculated banana tissues}

We investigated whether Kayinja and Mbwazirume differ in terms of $\mathrm{H}_{2} \mathrm{O}_{2}$ production in response to $X \mathrm{~cm}$ infection by staining tissues with DAB. Tissue sections from $\mathrm{Xcm}$-inoculated plants

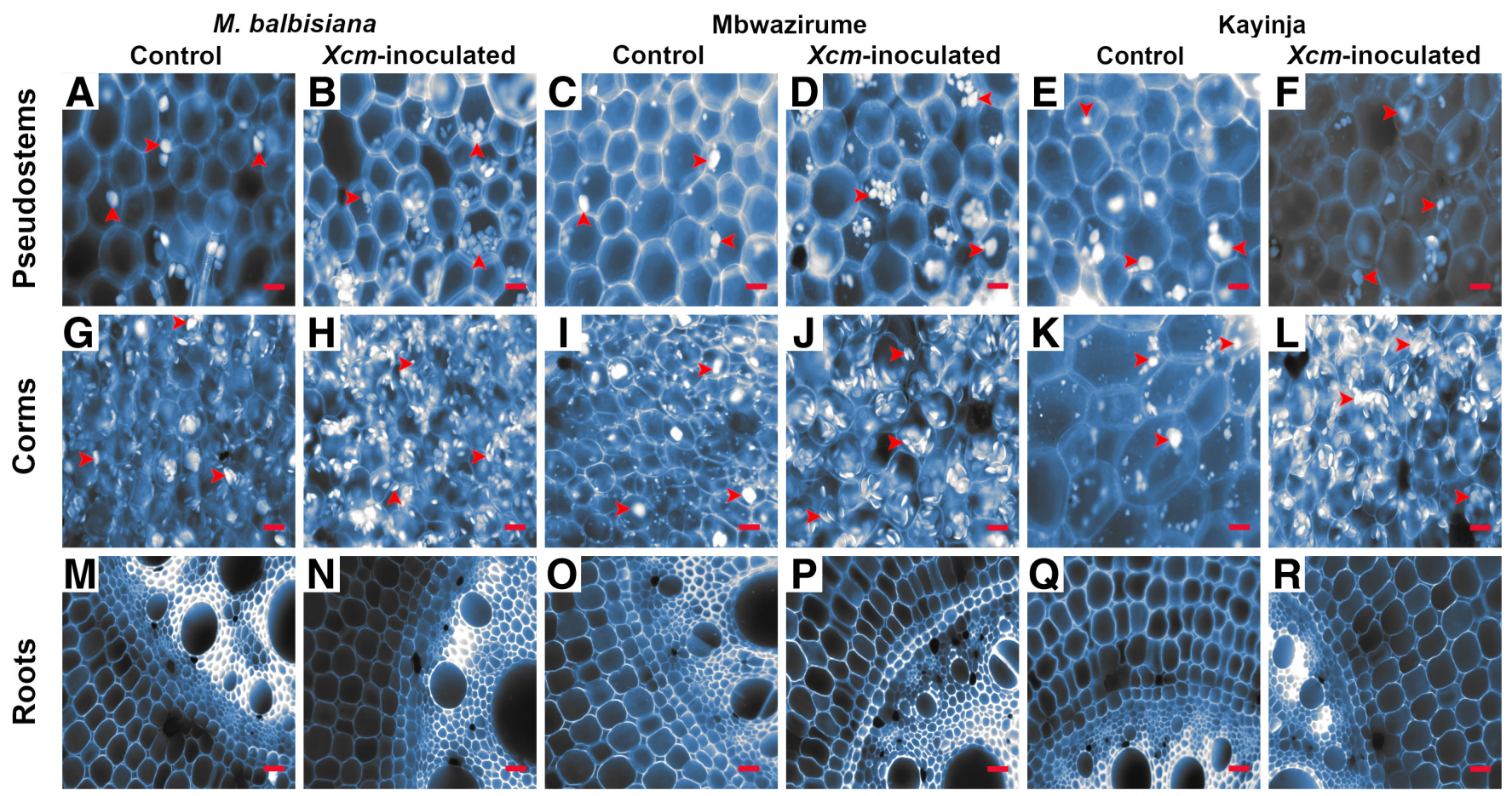

FIGURE 3

Callose deposition in different banana genotypes in response to Xanthomonas campestris pv. musacearum (Xcm) infection. Callose deposition (white fluorescing particles shown by the red arrowheads) at 14 days postinoculation obtained by fluorescence microscopy of aniline blue-stained sections of pseudostems ( $\mathbf{A}$ to $\mathbf{F}$ ), corms ( $\mathbf{G}$ to $\mathbf{L}$ ), and roots ( $\mathbf{M}$ to $\mathbf{R})$ in the three banana genotypes. Callose was consistently detected in pseudostems (A to $F$ ) and corms ( $G$ to $L$ ) but not in roots ( $M$ to $R$ ). Callose deposition was greater in $X \mathrm{~cm}$-inoculated plants than in control plants. All images were taken at $100 \times$ magnification using an AxioScope microscope (Carl-Zeiss, Oberkochen, Germany). Scale bar represents $200 \mu \mathrm{m}$. Experiments were performed in triplicate and repeated two times with similar results (ANOVA, $n=16, P<0.05$ ). 
showed a relatively dense DAB stain compared with controls (Fig. 4), with the exception of pseudostems of Kayinja and corms of both Kayinja and Mbwazirume, which showed DAB stain in controls (Fig. 4B, C, and O). There was a tendency of the DAB stain to accumulate in patches within areas surrounding vascular tissues of the pseudostems and leaves (Fig. 4D, E, G, H and P, $\mathrm{Q}, \mathrm{V}, \mathrm{W})$. In contrast, the corms showed the presence of stains in the form of vesicle-like structures that were randomly distributed across the corm tissue (Fig. 4C, F, I and O, R, U). There were only slight and subtle differences in intensity and frequency of the DAB stain between tissues over time after infection with $X \mathrm{~cm}$. For example, although tissues at 6 hpi showed a consistent DAB stain across all tissues (Fig. 4G to I and S to U), this was not the case at the other time points.

\section{Variations in $\mathrm{H}_{2} \mathrm{O}_{2}$ production in $\mathrm{Xcm}$-inoculated banana tissues}

Our study showed that $\mathrm{H}_{2} \mathrm{O}_{2}$ concentrations varied significantly between $\mathrm{Xcm}$-inoculated and control plants (Welch's ANOVA, $F_{(1,125.13)}=7.48, P=0.007$ ) (Table 4, Fig. 5, Supplementary Fig. S2C). Additionally, $\mathrm{H}_{2} \mathrm{O}_{2}$ concentration varied significantly between the different organs, with the pseudostem producing the highest $\mathrm{H}_{2} \mathrm{O}_{2}$ as compared with the leaves and corms (Welch's ANOVA, $F_{(2,104.59)}=3.88, P=0.024$ ) (Table 4, Fig. 5, Supplementary Fig. S2C). The ANOVA results also show that $\mathrm{H}_{2} \mathrm{O}_{2}$ production significantly varied across the sampling time points (Welch's ANOVA, $F_{(4,86.158)}=25.94, P<0.001$ ) (Table 4, Fig. 5, Supplementary Fig. S2C). In studied tissues of both genotypes, there was an initial transient spike in $\mathrm{H}_{2} \mathrm{O}_{2}$ observed at $1 \mathrm{hpi}$, followed by a decline at 3 to $6 \mathrm{hpi}$, and then another increase detected at $12 \mathrm{hpi}$ (Fig. 5). There was a biphasic $\mathrm{H}_{2} \mathrm{O}_{2}$ production in the tissues of $\mathrm{Xcm}$-inoculated plants, which yielded a peak of 10.21 to $18.92 \mathrm{~mol} /$ liter at $1 \mathrm{hpi}$, followed by a decrease to 2.44 to $4.81 \mathrm{~mol} / \mathrm{liter}$ at $6 \mathrm{hpi}$ and a further increase of 5.71 to 15.42 at 12 hpi. Constitutive and differential production of $\mathrm{H}_{2} \mathrm{O}_{2}$ in the banana tissues at 0 hpi varied between 1.12 and $6.77 \mathrm{~mol} /$ liter, with the highest constitutive $\mathrm{H}_{2} \mathrm{O}_{2}$ production observed in the pseudostem tissues and lowest in the corm tissues (Fig. 5). Control plants generally showed constant production of $\mathrm{H}_{2} \mathrm{O}_{2}$ in all the tissues between 3 and 12 hpi. These results also show that there was no significant difference in $\mathrm{H}_{2} \mathrm{O}_{2}$ production between the genotypes studied (ANOVA, $F_{(1,178)}=0.08, P=$ 0.779) (Table 4, Supplementary Fig. S2C).

\section{DISCUSSION}

\section{$X c m$ infection in banana stimulates production of callose and $\mathrm{H}_{2} \mathrm{O}_{2}$}

In this study, we examined the $\mathrm{Xcm}$-mediated callose deposition and $\mathrm{H}_{2} \mathrm{O}_{2}$ production as early defense signals in $\mathrm{BXW}$ and demonstrated for the first time striking variations between vegetative organs of the banana plants. Furthermore, these differences were independent of resistant or susceptible genotypes. A previous study showed that resistance to BXW in M. balbisiana is not due to hypersensitive response, systemic acquired resistance, or induced systemic resistance (Ssekiwoko et al. 2015). However, another study showed that $\mathrm{Xcm}$-mediated upregulation of biotic stress-related genes was higher in M. balbisiana than in the BXWsusceptible Kayinja (Tripathi et al. 2019), indicating activation of both PTI and ETI. Our findings described here show that callose and $\mathrm{H}_{2} \mathrm{O}_{2}$ are physiological signatures of PTI in banana-Xcm interaction.

Callose was present in banana tissues prior to inoculation because besides plant immunity, callose is widely distributed naturally and participates in numerous biological processes in plants, such as development and plasmodesmata function (Nedukha 2015; Piršelová et al. 2012; Schneider et al. 2016). The increase in $X \mathrm{~cm}$-mediated callose deposition suggests the central significance of callose in defense against $\mathrm{Xcm}$ in bananas. Similarly, a rapid increase in $\mathrm{H}_{2} \mathrm{O}_{2}$ suggests an oxidative burst as one of the earliest responses in banana defense against $\mathrm{Xcm}$. Previous studies in bananas (e.g., De Ascensao and Dubery 2000; Van Den Berg et al. 2007) reported no change in callose deposition in either tolerant banana cv. Goldfinger or susceptible cv. Williams challenged with Fusarium oxysporum f. sp. cubense. Instead, tolerance was associated with induction of cell wall-associated phenolic compounds (De Ascensao and Dubery 2000; Van Den Berg et al. 2007). In contrast, callose is required for resistance to $X$. campestris pv. campestris, and xanthan induces susceptibility in Nicotiana benthamiana and Arabidopsis by suppressing the callose deposition (Yun et al. 2006). In pepper, strong accumulation of callose and $\mathrm{H}_{2} \mathrm{O}_{2}$ was detected upon infection with $X$. campestris pv. vesicatoria $(X c v)$ deficient in $X o p B$ type- 3 effector protein that is known to interfere with these responses (Priller et al. 2016; Üstün et al. 2013). Furthermore, X. citri pv. citri, using its HrpE protein (which is a component of the type III secretion system), triggers defense responses in host and

TABLE 4

Hydrogen peroxide quantification by spectrophotometry in moles per liter in the two banana genotypes inoculated with Xanthomonas campestris pv. musacearum $(\mathrm{Xcm})^{\mathrm{z}}$

\begin{tabular}{|c|c|c|c|c|c|c|}
\hline Factors & $\mathrm{Df}_{1}, \mathrm{Df}_{2}$ & $F$ & $P$ & Factor levels & $N$ & $\overline{\mathrm{X}} \pm$ SEM \\
\hline Genotype & 1,178 & 0.08 & 0.779 & $\begin{array}{l}\text { Kayinja } \\
\text { Mbwazirume }\end{array}$ & $\begin{array}{l}90 \\
90\end{array}$ & $\begin{array}{l}7.81 \pm 0.41 \\
7.65 \pm 0.39\end{array}$ \\
\hline Treatment & $1,125.13$ & 7.48 & ${ }^{\overline{\mathrm{T}}} 0.007$ & $\begin{array}{l}\text { Control } \\
\mathrm{Xcm}\end{array}$ & $\begin{array}{l}90 \\
90\end{array}$ & $\begin{array}{l}6.98 \pm 0.23 \\
8.48 \pm 0.50\end{array}$ \\
\hline Organ & $2,104.59$ & 3.88 & ${ }^{\overline{\mathrm{T}}} 0.024$ & $\begin{array}{l}\text { Leaves } \\
\text { Pseudostems } \\
\text { Corms }\end{array}$ & $\begin{array}{l}60 \\
60 \\
60\end{array}$ & $\begin{array}{l}7.29 \pm 0.25 \mathrm{a} \\
8.57 \pm 0.39 \mathrm{~b} \\
7.33 \pm 0.69 \mathrm{a}\end{array}$ \\
\hline Time (hpi) & $4,86.158$ & 25.94 & $\overline{\mathrm{T}}<0.001$ & $\begin{array}{l}0 \\
1 \\
3 \\
6 \\
12\end{array}$ & $\begin{array}{l}36 \\
36 \\
36 \\
36 \\
36\end{array}$ & $\begin{array}{r}5.02 \pm 0.46 \mathrm{a} \\
11.79 \pm 0.68 \mathrm{c} \\
7.89 \pm 0.39 \mathrm{~b} \\
5.48 \pm 0.31 \mathrm{a} \\
8.46 \pm 0.50 \mathrm{~b}\end{array}$ \\
\hline
\end{tabular}

\footnotetext{
${ }^{\mathrm{z}}$ Means at each factor level followed by different letters indicate significant differences (ANOVA or Welch's ANOVA, $P<0.05$ ). The symbol ${ }^{\bar{\top}}$ indicates Welch's ANOVA. For data that violated Levene's test for homogeneity of variance, Welch's ANOVA was used. Data are shown as mean \pm standard error of the mean. Experiments were performed in triplicate and repeated two times with similar results.
} 
non-host plants that include callose deposition, $\mathrm{H}_{2} \mathrm{O}_{2}$ production, and other responses (Gottig et al. 2018). The drop in $\mathrm{H}_{2} \mathrm{O}_{2}$ production shown in our study at 6 hpi could be explained by the activity of $\mathrm{H}_{2} \mathrm{O}_{2}$-scavenging enzymes such as superoxide dismutase, ascorbate peroxidase, and catalase (Gambino et al. 2013; Kreslavski et al. 2013). The biphasic $\mathrm{H}_{2} \mathrm{O}_{2}$ production observed in our study was similar to Cui et al. (2019), in which $\mathrm{H}_{2} \mathrm{O}_{2}$ was produced in a biphasic manner in the xylem tissues of wounded Dalbergia odorifera stems, with the first peak at $2 \mathrm{hpi}$, followed by a drop at $6 \mathrm{hpi}$, a second peak at $12 \mathrm{hpi}$, and then a further drop at 24 hpi. Similarly, Edreva et al. (2015) observed a biphasic production of $\mathrm{H}_{2} \mathrm{O}_{2}$ in UV-B-irradiated cell suspension cultures of the green microalga Chlorella vulgaris, with the first peak at $30 \mathrm{~min}$ and second peak at $4 \mathrm{~h}$ post exposure. They propose that the first peak could have signal functions, whereas the second one that is longer and more sustained could play a vital role in initiation of programmed cell death (Edreva et al. 2015). Biphasic production of $\mathrm{H}_{2} \mathrm{O}_{2}$ in plant defense against biotic and abiotic stress have also been reported elsewhere (Castro et al. 2021; Pellegrini et al. 2013; Wi et al. 2012). Callose production peaking at between 14 and 28 dpi followed by a progressive decline in the different organs is consistent with the time needed for appearance of BXW symptoms at 11 to $21 \mathrm{dpi}$ as observed under this study and previously under field conditions (Smith et al. 2008; Tushemereirwe et al. 2004), suggesting possible correlations between onset of symptoms and decline in callose production. Similarly, decline in callose depositions coinciding with the onset of symptoms was previously observed in pepper infected with $X c v$ (Priller et al. 2016) and tomato infected with Pseudomonas syringae (Popov et al. 2016).

\section{Vegetative organs of banana vary in their $\mathrm{Xcm}$-mediated responses}

The banana organs showed differences in responses to infection, suggesting variable abilities of different organs in banana response to $X \mathrm{~cm}$. This was surprising because pathogen-induced callose deposition is known to be localized to callosic papillae, providing strategic structural defense against pathogens and providing targeted delivery of chemical defenses at the sites of pathogen attack (Chowdhury et al. 2014; Ellinger and Voigt 2014; Kashyap et al. 2020; Schneider et al. 2016). Similarly, $\mathrm{H}_{2} \mathrm{O}_{2}$ activates antimicrobial defenses at or near sites of infection, stimulating hypersensitive response to limit pathogens to the infection site (Bigeard et al. 2015; Jambunathan 2010; Torres et al. 2006). We therefore anticipated the highest callose deposition in the aerial banana organs, such as leaves and pseudostems, because $\mathrm{Xcm}$ naturally gains entry via the aerial tissues. However, this was not the case. Our results showed the highest $\mathrm{Xcm}$-mediated callose in corms, indicating that the corm could be the main organ of $X \mathrm{~cm}$-mediated callose-based defenses. In contrast, the highest $\mathrm{Xcm}$-mediated $\mathrm{H}_{2} \mathrm{O}_{2}$ was shown in the pseudostem. These

\section{Kayinja}

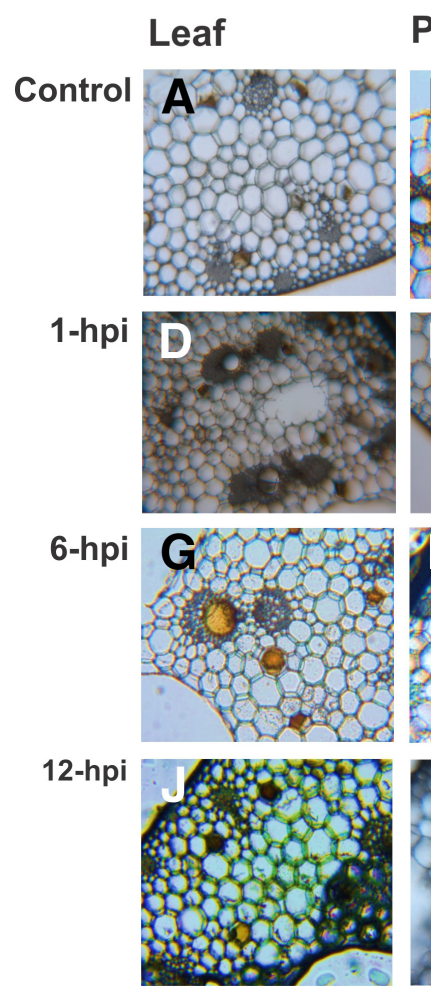

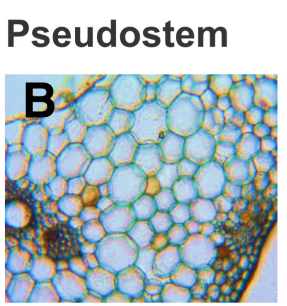

\section{Corm}
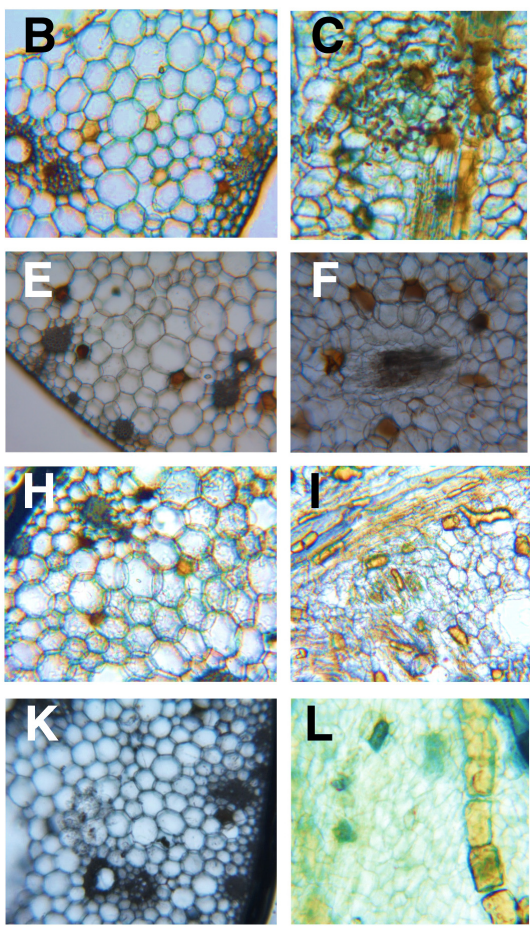
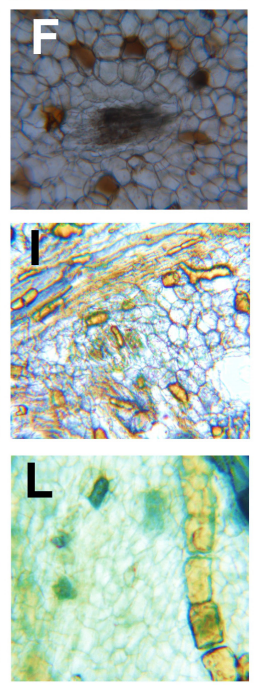

\section{Mbwazirume}

\section{Leaf}
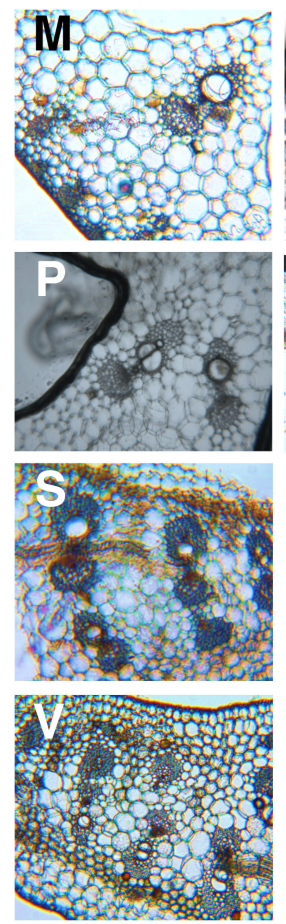

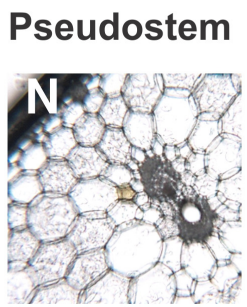

Corm
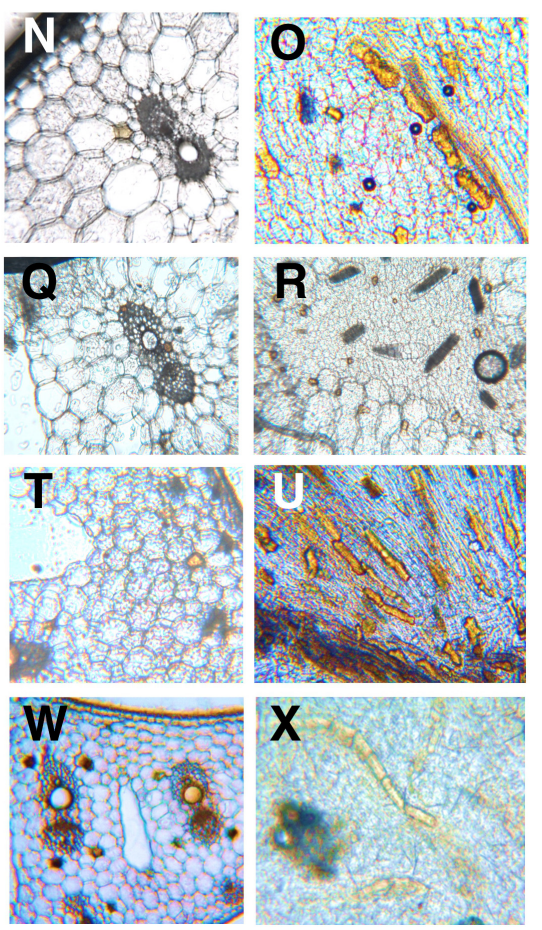

FIGURE 4

Hydrogen peroxide $\left(\mathrm{H}_{2} \mathrm{O}_{2}\right)$ production observed by 3,3'-diaminobenzidine (DAB) staining and visualization of the yellow-orange precipitate by microscopy in banana tissues (leaf, pseudostem, and corm) of Kayinja and Mbwazirume genotypes following inoculation with $\mathbf{X c m}$. Non-inoculated control samples (top row, $\mathbf{A}$ to $\mathbf{C}$ and $\mathbf{M}$ to $\mathbf{O}$ ) and 1, 6, and $12 \mathrm{~h}$ postinoculation (rows 2 to 4 ) are shown. The brown precipitate from DAB staining accumulated in patches near vascular tissues of leaves ( $D$ to $\mathbf{E}$ and $\mathbf{G}$ to $\mathbf{H}$ ) and pseudostems ( $\mathbf{P}$ to $\mathbf{Q}$ and $\mathbf{V}$ to $\mathbf{W}$ ) compared with randomly distributed vesicle-like structures across the corm tissue $(\mathbf{C}, \mathbf{F}, \mathbf{I}$ and $\mathbf{O}, \mathbf{R}, \mathbf{U})$. All images are of $50 \times$ magnification and were taken using a Zeiss-Axiocam digital camera, mounted on an AxioScope microscope (Carl-Zeiss, Oberkochen, Germany). Experiments were performed in triplicate and repeated two times, generating consistent results. 
findings suggest organ-based defense responses against Xcm or organ-specific determinants of resistance/susceptibility similar to what was previously observed in other pathosystems (Chuberre et al. 2018; Lyons et al. 2015; Park and Ryu 2015; Song et al. 2016; Strugala et al. 2015). For example, defense mechanisms against some pathogenic fungi differ in the roots and leaves of the same plant (Heath 1991; Jansen et al. 2006; Strugala et al. 2015). In maize, roots show a stronger defense response than leaves on shoot inoculation with Colletotrichum graminicola (Balmer et al. 2013). Similarly, strong differences in callose expression and callose synthase activities were observed in stem, leaf blade, and spike tissues of wheat, suggesting organ-specific expression patterns (Voigt et al. 2006). Leaves and tubers of potato (Solanum tuberosum) activate contrasting defense responses in terms of reactive oxygen species production and activation of defense genes following treatments with Phytophthora PAMP Pep-25 or bacterial PAMP flg22, indicating organ-specific responses to PAMPs (Lacaze and Joly 2022). Although most of these organ-specific defenses are in response to phytopathogenic fungi and in relatively smaller plants compared with bananas, it seems reasonable that organ-specific responses observed in the current study are more of a rule than an exception.

\section{The corm is essential in $\mathrm{Xcm}$-mediated responses in banana}

The banana corm is a subterranean modified stem, provides attachment for the roots, and serves as an organ of perennation supporting vegetative and perennial continuity of the crop across seasons. In this sense, its active participation ensuring a disease-free next generation should be a relevant feature. Plants on the same "mat" are anatomically connected with each other via the corm (Robinson and Galán Saúco 2010; Skutch 1932) in which $\mathrm{Xcm}$-mediated defenses under this study could be viewed as a form a "mother-to-offspring" transmission bottleneck against $X \mathrm{~cm}$ into lateral shoots. Generally, growth and developmental programs of plants are constrained by trade-offs with defense against pathogens depending on what is most essential at a given time (Huot et al. 2014; Karasov et al. 2017; Smakowska et al. 2016). Therefore, a BXW-infested mother plant on the corm might be sacrificed at the expense of $X \mathrm{~cm}$-mediated defense for healthy or latently infected lateral shoots. As such, incomplete systemic movement of $\mathrm{Xcm}$ in mats coupled with a gradual decline of bacterial load in subsequent generations to levels that cannot initiate (or take very long, 5 to 16 months to initiate) disease have been observed (Ocimati et al. 2013, 2015). We observed the characteristic orange-yellowish bacterial ooze from the cut surfaces of corms of inoculated plants of Kayinja and Mbwazirume (data not shown) but did not test for $\mathrm{Xcm}$ in those tissues. Our expectation is that bacterial invasion into the corm should be relatively low because of leaf- and pseudostem-based defense barriers mounted prior to entry into the corm. Additionally, mother banana plants can be 3 to $6 \mathrm{~m}$ tall (Robinson and Galán Saúco 2010; Skutch 1932); the distal location of the corm with respect to leaves as entry points for the bacteria could provide an "anatomical leverage" for the plant to assemble defenses in the corm and/or escape the infection of the lateral shoots. Previously, no diseased plants were observed in corm-inoculated Mbwazirume plants, and for Kayinja, only 1 to $15 \%$ of mild symptom incidences were observed along the true stem and fruit of some plants (Nakato et al. 2014). This study found no significant differences between the control and the corm inoculation for all symptoms compared with inoculations made in other tissues. In contrast, flower-inoculated plants show fast $\mathrm{Xcm}$ movement through the true stem to the leaf sheaths and corm of the mother plants and from where the bacteria invade the corm and the pseudostem of the attached suckers (Ssekiwoko et al. 2006a). It is plausible that the $\mathrm{Xcm}$-mediated defenses observed in our study promote attenuation of $X \mathrm{~cm}$ progression from leaves, which constrains bacterial entry from the pseudostem into younger lateral shoots via the corm; hence, the entire plant in susceptible varieties is sacrificed at the expense of the lateral shoots on the same mat. Whether faster disease development and/or defense responses could arise from flower rather than leaf inoculations of $\mathrm{Xcm}$ in bananas is an interesting future topic to study. Thus, in early stages of infection, the bacteria are restricted to the upper parts of the true stem (Ssekiwoko et al. 2006a) (and pseudostem), and these enable successful SDSR for BXW management in which diseased banana stems are aseptically removed at the soil (or corm) level immediately after observation of leaf or fruit symptoms (Kubiriba et al. 2014).
A

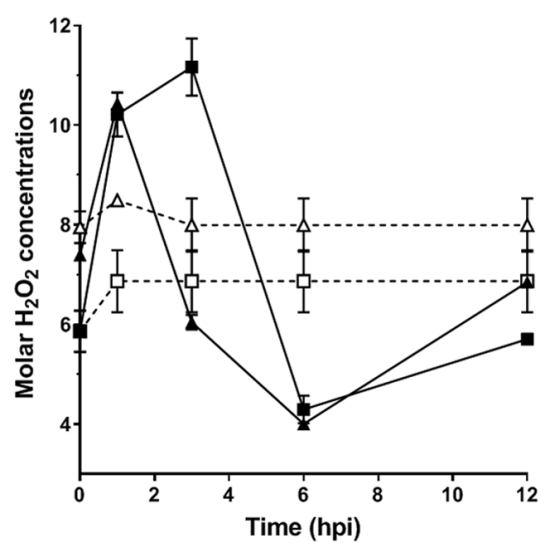

B

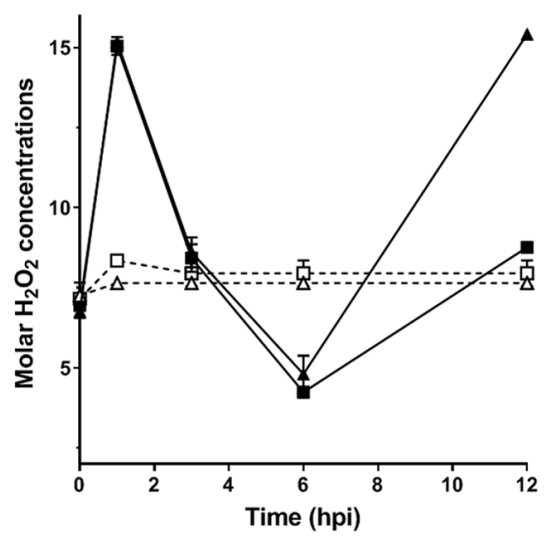

C

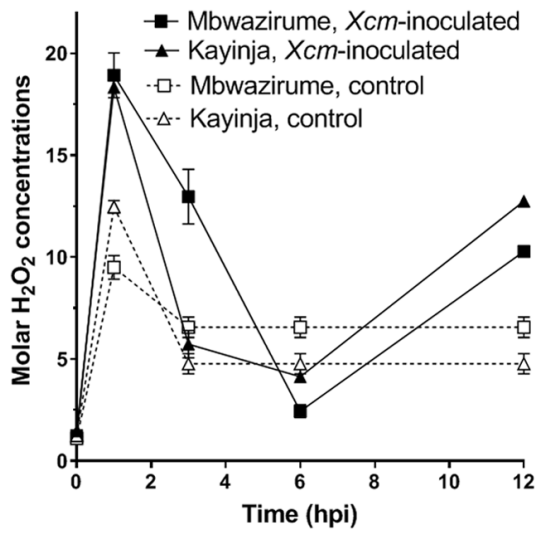

\section{FIGURE 5}

Quantitative variation in mean concentration of hydrogen peroxide $\left(\mathrm{H}_{2} \mathrm{O}_{2}\right)$ ( $\left.\mu \mathrm{mol} / \mathrm{liter}\right)$ in the leaf $(\mathbf{A})$, pseudostem (B), and corm (C) tissues of Xanthomonas campestris pv. musacearum $(\mathrm{Xcm})$-inoculated and control plants of Kayinja and Mbwazirume as assessed between 0 and $12 \mathrm{~h}$ postinoculation (hpi). All tissues showed an initial transient spike in $\mathrm{H}_{2} \mathrm{O}_{2}$ at 1 hpi, followed by a decline at 3 to 6 hpi and a second spike at $12 \mathrm{hpi}$. Differences between treatments, organs, and time points were significant $(P<0.01)$, whereas they were not significant between genotypes $(P>0.05)$ (Table 4). Experiments were performed in triplicate and repeated two times, generating consistent results. 


\section{Xcm-mediated callose and $\mathrm{H}_{2} \mathrm{O}_{2}$ alone do not account for resistance to $\mathrm{BXW}$}

Although all the banana genotypes grown in ECA are susceptible and succumb to BXW once infected (Nakato et al. 2019; Ssekiwoko et al. 2006b, 2013; Tripathi et al. 2008), previous observations show that Kayinja is relatively more susceptible than Mbwazirume (Nakato et al. 2019; Ssekiwoko et al. 2006b; Tripathi et al. 2008). This differential susceptibility was also observed under our study because Kayinja plants succumbed to BXW faster than did Mbwazirume. However, no significant differences in $\mathrm{H}_{2} \mathrm{O}_{2}$ production were found between susceptible and resistant genotypes under this study, suggesting that these responses alone might not account for the observed differential susceptibilities between these genotypes. Moreover, the results were unexpected for $M$. balbisiana (analyzed only for callose deposition under this study) because this genotype is resistant to BXW (Nakato et al. 2019; Ssekiwoko et al. 2006b, 2013; Tripathi et al. 2008); however, under this study, it could not be differentiated from susceptible genotypes by the ELISA method. The observed difference between ELISA and fluorescence microscopy results for callose quantification in the genotypes could have been due to the sensitivity of the two methods because ELISA is prone to false positives and could have less discriminating power. Although $\mathrm{Xcm}$ disables host detection systems and related downstream reactions in both resistant and susceptible genotypes, the bacteria fail to establish in M. balbisiana, where their multiplication and migration was slowed and subsequently cleared from host tissues (Ssekiwoko et al. 2013, 2015). A recent study showed that many of the differentially expressed genes (that mapped to the biotic stress pathways) were higher in M. balbisiana than in Kayinja, suggesting activation of early response to $X \mathrm{~cm}$ infection via both PTI and ETI in M. balbisiana (Tripathi et al. 2019). These authors further observed suppression of most genes associated with $\beta$-1,3-glucanases that degrade callose to ensure callose accumulation in M. balbisiana after inoculation with $X \mathrm{~cm}$ at $12 \mathrm{hpi}$, suggesting cell-wall enforcement by callose deposition. Pathogen-derived callose deposition is one of the early defense "hallmarks" in plants against pathogens (Voigt 2014; Wang et al. 2021). Our results indicate that although a substantial amount of callose deposition occurs in response to $\mathrm{Xcm}$ infection, callose alone might not account for BXW resistance in M. balbisiana. Even though the fluorescence microscopy results showed that there was significant callose production between $M$. balbisiana and Kayinja, this was not the case with Mbwazirume, whereas the ELISA method showed no significant variation in callose production between all three genotypes. Furthermore, neither hypersensitive response nor systemic acquired resistance or induced systemic resistance accounts for the resistance of $M$. balbisiana against Xanthomonas vasicola pv. musacearum (Xvm, alias Xcm) because the bacteria suppress key genes in these pathways (Ssekiwoko et al. 2013, 2015). Therefore, other processes yet to be identified could promote resistance in M. balbisiana. One possibility is that there are numerous interactions between PTI pathways such that callose deposition becomes part of the complex network culminating in resistance in $M$. balbisiana. For example, powdery mildew-resistant 4 ( $p m r 4$ ), a mutant lacking pathogeninduced callose, is resistant to pathogens rather than more susceptible because the pmr4 mutant is associated with hyperactivation of salicylic acid signaling, leading to increased resistance in Arabidopsis (Nishimura et al. 2003). Similar observations have been made in tomatoes (Huibers et al. 2013; Santillán Martínez et al. 2020). Additionally, tolerance of banana to fusarium wilt was linked to significantly increased induction of cell wallassociated phenolic compounds (Van Den Berg et al. 2007).
Defense responses of resistant and susceptible banana cultivars treated with biological control agents and Fusarium oxysporum f. sp. cubense were regulated by differentially expressed genes in numerous categories of defense pathways (Kaushal et al. 2021). According to Ssekiwoko et al. (2013), M. balbisiana resists Xcm by slowing the multiplication and migration of the bacterium, followed by subsequent death of the affected organs together with the $X \mathrm{~cm}$, which accounts for delayed symptoms and later recovery. Indeed, the assembly of different physico-chemical or structural barriers to pathogen migration is a hallmark for vascular wilt pathogens intended to limit the pathogen spread to distant tissues (Beckman et al. 1982; Kashyap et al. 2020; Lee et al. 2019; Planas-Marquès et al. 2020; Pouzoulet et al. 2017; Robb et al. 1991; Schneider et al. 2016; Sebastià et al. 2021). Such physico-chemical/structural barriers could include a myriad of phenolic compounds, lignin, suberin, tyloses, gels, and callose. In Solanum dulcamara, a reservoir host for Ralstonia solanacearum, resistance to the bacterial wilt is due to restricted colonization of the bacteria (Sebastià et al. 2021). It is reasonable that $X \mathrm{~cm}$ resistance in $M$. balbisiana could be a multicomponent strategy curtailing the multiplication and migration of bacteria, the dissection of which will benefit from future studies.

\section{Detectability of callose in roots by fluorescence microscopy and ELISA methods}

Callose deposition was determined under this study using two independent methods: fluorescence microscopy and ELISA (Piršelová and Matušíková 2013). These were applied for the first time to bananas. Fluorescence microscopy is a well-established method based on staining with aniline, which forms fluorescing complexes (Stone et al. 1984). In contrast, the ELISA method, which is not well-established, is based on enzyme immunoassay used to detect the presence of an antigen/ligand (in this case, callose) in the crude $1 \mathrm{M} \mathrm{NaOH}$ banana extract using antibodies directed against callose (Anderson and McNellis 1998; Engvall and Perlmann 1971; Van Weemen and Schuurs 1971). Although a few differences were observed in the data (e.g., the peaking of callose deposits in the different tissues), statistical analysis largely showed congruence of fluorescence microscopy and ELISA data, indicating consistency in the two methods of callose detection. However, we highlight that ELISA is highly prone to false positives (Anderson and McNellis 1998; Hosseini et al. 2018) and could be less reliable than the well-established aniline blue staining and direct observations of callose. For example, no fluorescing callose particles were observed in the root tissues under fluorescent microscopy. We first viewed this to imply that banana roots are irrelevant with respect to $\mathrm{Xcm}$-mediated defense, but ELISA provided contradictory results, indicating the abundance of $X \mathrm{~cm}$-mediated callose in the banana roots. Indeed, both constitutive and pathogen-mediated callose deposits can be found in the roots of plant species (Bonhoff et al. 1987; Daayf et al. 1997), although root callose could also arise from soilborne heavy metal contamination (Nedukha 2015; Piršelová et al. 2012; Tahara et al. 2005; Wissemeier et al. 1992; Zhang et al. 2015). Indeed, the discrepancy between aniline blue staining and ELISA could be accounted for by the fact that ELISA is prone to false positives and requires further analysis, including studies of the physico-chemical properties and anatomical assembly of banana tissues. One possibility is that callose in the roots of banana might occur in "isoforms" that do not easily form complexes with aniline blue compared with the isoforms that exist in the other tissues, although both types could be easily detectable by ELISA. For example, whereas most of the callose is characterized by $(1,3)-\beta$-branches, some $(1,6)-\beta$-branches also occur 
(Aspinall and Kessler 1957; Chen and Kim 2009; Stone and Clarke 1992), which could account for variances in biochemistry and/or detectability by different methods. Such is the case in a laticiferous plant, Euphorbia heterophylla, in which laticifer walls differ from those of their surrounding cells in that the level of a $(1 \rightarrow 4) \beta$-D-galactan epitope is much lower in laticifers than in other cells (Serpe et al. 2004). Consequently, an anti- $(1 \rightarrow 3) \beta$ D-glucan antibody that recognizes callose failed to label laticifer walls and those walls immediately adjacent to laticifers, but it produced a punctuated labeling pattern in most other cells (Serpe et al. 2004). The second possibility is that different plant tissues might accumulate various primary or secondary metabolites, which, at higher concentrations, could obscure or interfere with fluorescent signal in aniline staining measurement (Ko and Lin 2004; Piršelová and Matušíková 2013; Smith and McCully 1978; Yan et al. 2015). Up to eight glucan synthase-like genes control callose synthesis and are regulated in an organ-specific manner in wheat (Voigt et al. 2006), whereas at least nine callose synthase genes in stinging nettle (Urtica dioica) show variable expression in roots and leaves (Guerriero et al. 2020). However, whether the differential controls in synthesis could generate different "forms" of callose or its complexes is unknown. The third possibility is that the various primary or secondary metabolites at higher concentrations in banana roots provide high background noise and, with the lower discriminating power of ELISA, could generate false positives of callose in root extracts. Overall, whereas results from the two methods were largely congruent, it is reasonable for the results from ELISA to be interpreted with caution, as the method still requires extensive optimization.

\section{CONCLUSIONS}

Overall, this is the first study to examine pathogen-mediated callose and $\mathrm{H}_{2} \mathrm{O}_{2}$ production at different tissue and organ levels in response to $\mathrm{Xcm}$ in bananas and the resulting BXW disease. Our findings point to an organ-specific response to $\mathrm{Xcm}$ infection in bananas that is independent of resistant or susceptible genotypes. Determination of callose deposits both qualitatively and quantitatively provided fair reproducibility of the data. Although $M$. balbisiana is resistant to $\mathrm{Xcm}$, it has not been possible to transfer the resistance to commercial banana cultivars to control BXW, partly because of the challenges associated with its introgression, and the resistance mechanism is also not well understood. Effective transgenic resistance against BXW in bananas is available; however, it suffers legislative impediments in the ECA region. Consequently, cultural methods have been used in the management of BXW (e.g., SDSR, in which only the BXW-diseased plant is removed from the corm while leaving the other symptomless lateral shoots). Pseudostems of infected plants accumulate high quantities of $\mathrm{H}_{2} \mathrm{O}_{2}$. Our findings that corm accumulates higher quantities of callose (and also $\mathrm{H}_{2} \mathrm{O}_{2}$ ) while also supporting a $\mathrm{H}_{2} \mathrm{O}_{2}$-loaded pseudostem provide a possible mechanistic basis by which $\mathrm{Xcm}$ progression into lateral shoots is slowed during natural infection. Therefore, corm plays an important role in $X \mathrm{~cm}$-mediated response to BXW. It is noteworthy that banana corm is a subterranean organ of perennation enabling perennial continuity of the crop seasons, and in this sense, active participation to ensure a disease-free next generation should be a desirable and relevant feature. Additional evidence is needed to determine whether $\mathrm{Xcm}$-medicated callose in the corm might be essential in limiting vertical transmission of $\mathrm{Xcm}$ into lateral shoots and whether this represents an example of trade-offs between plant development and defense against pathogens. Contrary to our expectations, susceptible and resistant genotypes under this study showed no significant differences in relation to levels of $\mathrm{Xcm}$ - derived callose and $\mathrm{H}_{2} \mathrm{O}_{2}$, indicating that these are not the primary responses that impart resistance to $\mathrm{BXW}$ in $M$. balbisiana. Future studies should be aimed at uncovering other defense responses in $M$. balbisiana that promote resistance against BXW. Furthermore, strategies that increase callose and $\mathrm{H}_{2} \mathrm{O}_{2}$ production in susceptible bananas without compromising yield could be a potential avenue for controlling BXW in the field.

\section{ACKNOWLEDGMENTS}

We are grateful to Aleš Soukup (Department of Plant Experimental Biology, Charles University in Prague, Czech Republic) for his technical assistance and helpful discussions on this study and to Mark P. Simmons (Colorado State University, U.S.A.) for constructive comments on this study. We thank the anonymous reviewers whose constructive criticism improved the manuscript.

\section{LITERATURE CITED}

Abele, S., Twine, E., and Legg, C. 2007. Food Security in Eastern Africa and the Great Lakes Region. Crop Crisis Control Project (C3P), USAID.

Adriko, J., Aritua, V., Mortensen, C. N., Tushemereirwe, W. K., Kubiriba, J., and Lund, O. S. 2012. Multiplex PCR for specific and robust detection of Xanthomonas campestris pv. musacearum in pure culture and infected plant material. Plant Pathol. 61:489-497.

Altenbach, D., and Robatzek, S. 2007. Pattern recognition receptors: From the cell surface to intracellular dynamics. Mol. Plant-Microbe Interact. 20:1031-1039.

Anderson, G. L., and McNellis, L. A. 1998. Enzyme-linked antibodies: A laboratory introduction to the ELISA assay. J. Chem. Educ. 75:1275.

Anderson, J. P., Gleason, C. A., Foley, R. C., Thrall, P. H., Burdon, J. B., and Singh, K. B. 2010. Plants versus pathogens: An evolutionary arms race. Funct. Plant Biol. 37:499-512.

Aspinall, G. O., and Kessler, G. 1957. The structure of callose from the grape vine. Chemistry and Industry, 1296.

Balmer, D., de Papajewski, D. V., Planchamp, C., Glauser, G., and MauchMani, B. 2013. Induced resistance in maize is based on organ-specific defence responses. Plant J. 74:213-225.

Beckman, C. H., Mueller, W. C., Tessier, B. J., and Harrison, N. A. 1982. Recognition and callose deposition in response to vascular infection in Fusarium wilt-resistant or susceptible tomato plants. Physiol. Plant Pathol. 20:1-10.

Beer. 1852. Bestimmung der Absorption des rothen Lichts in farbigen Flüssigkeiten. Ann. Phys. 162:78-88.

Bigeard, J., Colcombet, J., and Hirt, H. 2015. Signaling mechanisms in pattern-triggered immunity (PTI). Molecular Plant 8:521-539.

Blomme, G., Ocimati, W., Sivirihauma, C., Vutseme, L., Mariamu, B., Kamira, M., van Schagen, B., Ekboir, J., and Ntamwira, J. 2017. A control package revolving around the removal of single diseased banana stems is effective for the restoration of Xanthomonas wilt infected fields. Eur. J. Plant Pathol. 149:385-400.

Bonhoff, A., Rieth, B., Golecki, J., and Grisebach, H. 1987. Race cultivarspecific differences in callose deposition in soybean roots following infection with Phytophthora megasperma f. sp. glycinea. Planta 172:101-105.

Castro, B., Citterico, M., Kimura, S., Stevens, D. M., Wrzaczek, M., and Coaker, G. 2021. Stress-induced reactive oxygen species compartmentalization, perception and signalling. Nat. Plants 7:403-412.

Chen, X.-Y., and Kim, J.-Y. 2009. Callose synthesis in higher plants. Plant Signal. Behav. 4:489-492.

Chowdhury, J., Henderson, M., Schweizer, P., Burton, R. A., Fincher, G. B., and Little, A. 2014. Differential accumulation of callose, arabinoxylan and cellulose in nonpenetrated versus penetrated papillae on leaves of barley infected with Blumeria graminis f. sp. hordei. New Phytol. 204:650-660.

Chuberre, C., Plancot, B., Driouich, A., Moore, J. P., Bardor, M., Gügi, B., and Vicré, M. 2018. Plant immunity is compartmentalized and specialized in roots. Front. Plant Sci. 9:1692.

Cohen, Y., Eyal, H., and Hanania, J. 1990. Ultrastructure, autofluorescence, callose deposition and lignification in susceptible and resistant muskmelon leaves infected with the powdery mildew fungus Sphaerotheca fuliginea. Physiol. Mol. Plant Pathol. 36:191-204.

Cui, Z., Yang, Z., and Xu, D. 2019. Synergistic roles of biphasic ethylene and hydrogen peroxide in wound-induced vessel occlusions and essential oil accumulation in Dalbergia odorifera. Front. Plant Sci. 10:250.

Daayf, F., Nicole, M., Boher, B., Pando, A., and Geiger, J. P. 1997. Early vascular defense reactions of cotton roots infected with a defoliating mutant strain of Verticillium dahliae. Eur. J. Plant Pathol. 103:125-136. 
Daudi, A., and O'Brien, J. A. 2012. Detection of hydrogen peroxide by DAB staining in Arabidopsis leaves. Bio Protoc. 2:e263.

De Ascensao, A. R., and Dubery, I. A. 2000. Panama disease: Cell wall reinforcement in banana roots in response to elicitors from Fusarium oxysporum f. sp. cubense race four. Phytopathology 90:1173-1180.

Dodds, P. N., and Rathjen, J. P. 2010. Plant immunity: Towards an integrated view of plant-pathogen interactions. Nat. Rev. Genet. 11:539-548.

Dotto, J. M., Matemu, A., and Ndakidemi, P. 2018. Potential of cooking bananas in addressing food security in East Africa. Int. J. Biosci. 13: 278-294.

Edreva, A. M., Pouneva, I. D., and Gesheva, E. Z. 2015. UV-B radiation induces biphasic burst of hydrogen peroxide in mesophyll Chlorella vulgaris. Russ. J. Plant Physiol. 62:219-223.

Ellinger, D., and Voigt, C. A. 2014. Callose biosynthesis in arabidopsis with a focus on pathogen response: What we have learned within the last decade. Ann. Bot. 114:1349-1358.

Engvall, E., and Perlmann, P. 1971. Enzyme-linked immunosorbent assay (ELISA). Quantitative assay of immunoglobulin G. Immunochemistry 8:871-874.

FAOSTAT. 2017. Accessed 6 June 2021. http://www.fao.org/faostat/en/ \#home

Gambino, G., Boccacci, P., Margaria, P., Palmano, S., and Gribaudo, I. 2013. Hydrogen peroxide accumulation and transcriptional changes in grapevines recovered from Flavescence dorée disease. Phytopathology 103:776-784

Games, P. A., and Howell, J. F. 1976. Pairwise multiple comparison procedures with unequal N's and/or variances: A Monte Carlo study. J. Educ. Stat. 1:113-125.

Gottig, N., Vranych, C. V., Sgro, G. G., Piazza, A., and Ottado, J. 2018. HrpE, the major component of the Xanthomonas type three protein secretion pilus, elicits plant immunity responses. Sci. Rep. 8:9842.

Guerriero, G., Piasecki, E., Berni, R., Xu, X., Legay, S., and Hausman, J.-F. 2020. Identification of callose synthases in stinging nettle and analysis of their expression in different tissues. Int. J. Mol. Sci. 21:3853.

Heath, M. C. 1991. Evolution of resistance to fungal parasitism in natural ecosystems. New Phytol. 119:331-343.

Hosseini, S., Vázquez-Villegas, P., Rito-Palomares, M., and Martinez-Chapa, S. O. 2018. Enzyme-Linked Immunosorbent Assay (ELISA) from A to Z. Springer Nature, Singapore.

Huibers, R. P., Loonen, A. E. H. M., Gao, D., Van den Ackerveken, G., Visser, R. G. F., and Bai, Y. 2013. Powdery mildew resistance in tomato by impairment of SLPMR4 and SLDMRI. PLoS One 8:e67467.

Huot, B., Yao, J., Montgomery, B. L., and He, S. Y. 2014. Growth-defense tradeoffs in plants: A balancing act to optimize fitness. Mol. Plant 7:12671287

Jambunathan, N. 2010. Determination and detection of reactive oxygen species (ROS), lipid peroxidation, and electrolyte leakage in plants. Pages 291-297 in: Plant Stress Tolerance: Methods and Protocols. R. Sunkar, ed. Humana Press, Totowa, NJ.

Jansen, M., Slusarenko, A. J., and Schaffrath, U. 2006. Competence of roots for race-specific resistance and the induction of acquired resistance against Magnaporthe oryzae. Mol. Plant Pathol. 7:191-195.

Jones, J. D. G., and Dangl, J. L. 2006. The plant immune system. Nature 444:323-329.

Karasov, T. L., Chae, E., Herman, J. J., and Bergelson, J. 2017. Mechanisms to mitigate the trade-off between growth and defense. Plant Cell 29:666-680.

Kashyap, A., Planas-Marquès, M., Capellades, M., Valls, M., and Coll, N. S. 2020. Blocking intruders: Inducible physico-chemical barriers against plant vascular wilt pathogens. J. Exp. Bot. 72:184-198.

Kaushal, M., Mahuku, G., and Swennen, R. 2021. Comparative transcriptome and expression profiling of resistant and susceptible banana cultivars during infection by Fusarium oxysporum. Int. J. Mol. Sci. 22:3002.

Khaledi, N., Taheri, P., and Falahati-Rastegar, M. 2018. Evaluation of resistance and the role of some defense responses in wheat cultivars to Fusarium head blight. J. Plant Prot. Res. 57:396-408.

Ko, Y. T., and Lin, Y. L. 2004. 1,3-Beta-glucan quantification by a fluorescence microassay and analysis of its distribution in foods. J. Agric. Food Chem. 52:3313-3318.

Kohari, M., Yashima, K., Desaki, Y., and Shibuya, N. 2016. Quantification of stimulus-induced callose spots on plant materials. Plant Biotechnol. 33:11-17.

Kohler, A., Schwindling, S., and Conrath, U. 2000. Extraction and quantitative determination of callose from Arabidopsis leaves. BioTechniques 28:1084-1086.

Kreslavski, V. D., Lyubimov, V. Y., Shirshikova, G. N., Shmarev, A. N., Kosobryukhov, A. A., Schmitt, F.-J., Friedrich, T., and Allakhverdiev, S. I. 2013. Preillumination of lettuce seedlings with red light enhances the resistance of photosynthetic apparatus to UV-A. J. Photochem. Photobiol. B 122:1-6.
Kubiriba, J., Muthomi, J., Ndungo, V., Kwach, J., Erima, R., Rwomushana, I., Tushemereirwe, W., and Opio, F. 2014. Strategies for rehabilitation of banana fields infested with Xanthomonas campestris pv. musacearum. J. Crop Prot. 3:21-29.

Kuźniak, E., and Urbanek, H. 2000. The involvement of hydrogen peroxide in plant responses to stresses. Acta Physiol. Plant. 22:195-203.

Lacaze, A., and Joly, D. L. 2022. Leaf and tuber treatments with PAMPs trigger organ-specific responses in potato. Can. J. Plant Pathol. 44: 115-127.

Lambert, J. H. 1760. Photometria sive de mensura et gradibus luminis, colorum et umbrae [Photometry, or, On the measure and gradations of light intensity, colors, and shade]; Eberhardt Klett: Augsburg, Germany, 1760.

Lee, M.-H., Jeon, H. S., Kim, S. H., Chung, J. H., Roppolo, D., Lee, H.-J., Cho, H. J., Tobimatsu, Y., Ralph, J., and Park, O. K. 2019. Lignin-based barrier restricts pathogens to the infection site and confers resistance in plants. EMBO J. 36:1-17.

Luna, E., Pastor, V., Robert, J., Flors, V., Mauch-Mani, B., and Ton, J. 2011. Callose deposition: A multifaceted plant defense response. Mol. PlantMicrobe Interact. 24:183-193.

Lyons, R., Stiller, J., Powell, J., Rusu, A., Manners, J. M., and Kazan, K. 2015. Fusarium oxysporum triggers tissue-specific transcriptional reprogramming in Arabidopsis thaliana. PLoS One 10:e0121902.

Malinovsky, F. G., Fangel, J. U., and Willats, W. G. T. 2014. The role of the cell wall in plant immunity. Front. Plant Sci. 5:178.

Moore, J. W., Loake, G. J., and Spoel, S. H. 2011. Transcription dynamics in plant immunity. Plant Cell 23:2809-2820.

Mwangi, M., Bandyopadhyay, R., Ragama, P., and Tushemereirwe, W. K. 2007. Assessment of banana planting practices and cultivar tolerance in relation to management of soilborne Xanthomonas campestris pv musacearum. Crop Prot. 26:1203-1208.

Nakato, G. V., Christelová, P., Were, E., Nyine, M., Coutinho, T. A., Doležel, J., Uwimana, B., Swennen, R., and Mahuku, G. 2019. Sources of resistance in Musa to Xanthomonas campestris pv. musacearum, the causal agent of banana Xanthomonas wilt. Plant Pathol. 68:49-59.

Nakato, V., Mahuku, G., and Coutinho, T. 2018. Xanthomonas campestris pv. musacearum: A major constraint to banana, plantain and enset production in central and east Africa over the past decade. Mol. Plant Pathol. 19: 525-536.

Nakato, V., Ocimati, W., Blomme, G., Fiaboe, K. K. M., and Beed, F. 2014. Comparative importance of infection routes for banana Xanthomonas wilt and implications on disease epidemiology and management. Can. J. Plant Pathol. 36:418-427.

Ndungo, V., Eden-Green, S., Blomme, G., Crozier, J., and Smith, J. J. 2006. Presence of banana Xanthomonas wilt (Xanthomonas campestris pv. musacearum) in the Democratic Republic of Congo (DRC). Plant Pathol. $55: 294$

Nedukha, O. 2015. Callose: Localization, functions, and synthesis in plant cells. Cytol. Genet. 49:49-57.

Nelson, T. E., and Lewis, B. A. 1974. Separation and characterization of the soluble and insoluble components of insoluble laminaran. Carbohydr. Res. 33:63-74.

Nicaise, V., Roux, M., and Zipfel, C. 2009. Recent advances in PAMPtriggered immunity against bacteria: Pattern recognition receptors watch over and raise the alarm. Plant Physiol. 150:1638-1647.

Nishimura, M. T., Stein, M., Hou, B.-H., Vogel, J. P., Edwards, H., and Somerville, S. C. 2003. Loss of a callose synthase results in salicylic acid-dependent disease resistance. Science 301:969-972.

Noctor, G., Lelarge-Trouverie, C., and Mhamdi, A. 2015. The metabolomics of oxidative stress. Phytochemistry 112:33-53.

O'Brien, J. A., Daudi, A., Butt, V. S., and Bolwell, G. P. 2012. Reactive oxygen species and their role in plant defence and cell wall metabolism. Planta 236:765-779.

Ocimati, W., Bouwmeester, H., Groot, J. C. J., Tittonell, P., Brown, D., and Blomme, G. 2019. The risk posed by Xanthomonas wilt disease of banana: Mapping of disease hotspots, fronts and vulnerable landscapes. PloS One 14:e0213691.

Ocimati, W., Nakato, G. V., Fiaboe, K. M., Beed, F., and Blomme, G. 2015. Incomplete systemic movement of Xanthomonas campestris pv. musacearum and the occurrence of latent infections in Xanthomonas wiltinfected banana mats. Plant Pathol. 64:81-90.

Ocimati, W., Ssekiwoko, F., Karamura, E., Tinzaara, W., Eden-Green, S., and Blomme, G. 2013. Systemicity of Xanthomonas campestris pv. musacearum and time to disease expression after inflorescence infection in East African Highland and Pisang Awak bananas in Uganda. Plant Pathol. 62:777-785.

Park, Y.-S., and Ryu, C.-M. 2015. Inter-organ defense networking: Leaf whitefly sucking elicits plant immunity to crown gall disease caused by Agrobacterium tumefaciens. Plant Signal. Behav. 10: e1081325. 
Patterson, B. D., MacRae, E. A., and Ferguson, I. B. 1984. Estimation of hydrogen peroxide in plant extracts using titanium (IV). Anal. Biochem. 139:487-492.

Pellegrini, E., Trivellini, A., Campanella, A., Francini, A., Lorenzini, G., Nali, C., and Vernieri, P. 2013. Signaling molecules and cell death in Melissa officinalis plants exposed to ozone. Plant Cell Rep. 32:1965-1980.

Piršelová, B., and Matušíková, I. 2013. Callose: The plant cell wall polysaccharide with multiple biological functions. Acta Physiol. Plant 35: 635-644.

Piršelová, B., Mistríková, V., Libantová, J., Moravčíková, J., and Matušíková, I. 2012. Study on metal-triggered callose deposition in roots of maize and soybean. Biologia (Bratisl) 67:698-705.

Planas-Marquès, M., Kressin, J. P., Kashyap, A., Panthee, D. R., Louws, F. J., Coll, N. S., and Valls, M. 2020. Four bottlenecks restrict colonization and invasion by the pathogen Ralstonia solanacearum in resistant tomato. J. Exp. Bot. 71:2157-2171.

Popov, G., Fraiture, M., Brunner, F., and Sessa, G. 2016. Multiple Xanthomonas euvesicatoria Type III effectors inhibit flg22-triggered immunity. Mol. Plant-Microbe Interact. 29:651-660.

Pouzoulet, J., Scudiero, E., Schiavon, M., and Rolshausen, P. E. 2017. Xylem vessel diameter affects the compartmentalization of the vascular pathogen Phaeomoniella chlamydospore in grapevine. Front. Plant Sci. 8:1442.

Priller, J. P. R., Reid, S., Konein, P., Dietrich, P., and Sonnewald, S. 2016. The Xanthomonas campestris pv. vesicatoria Type-3 Effector XopB inhibits plant defence responses by interfering with ROS production.. PloS One 11:e0159107.

R Core Team. 2020. R: A Language and Environment for Statistical Computing (Version 3.6.3). R Foundation for Statistical Computing, Vienna, Austria. https://www.r-project.org/

Reen, D. J. 1994. Enzyme-linked immunosorbent assay (ELISA). Pages 461466 in: Basic Protein and Peptide Protocols. J. M. Walker, ed. Humana Press, Totowa, NJ.

Rioux, L. E., Turgeon, S. L., and Beaulieu, M. 2007. Characterization of polysaccharides extracted from brown seaweeds. Carbohydr. Polym. 69:530-537.

Robb, J., Lee, S.-W., Mohan, R., and Kolattukudy, P. E. 1991. Chemical characterization of stress-induced vascular coating in tomato. Plant Physiol. 97:528-536.

Robinson, J. C., and Galán Saúco, V. 2010. Bananas and Plantains. MPG Books Group, Cambridge, MA.

Santillán Martínez, M. I., Bracuto, V., Koseoglou, E., Appiano, M., Jacobsen, E., Visser, R. G. F., Wolters, A.-M. A., and Bai, Y. 2020. CRISPR/Cas9targeted mutagenesis of the tomato susceptibility gene $P M R 4$ for resistance against powdery mildew. BMC Plant Biol. 20:284

Schenk, S. T., and Schikora, A. 2015. Staining of callose depositions in root and leaf tissues. Bio-protocol 5:e1429.

Schneider, R., Hanak, T., Persson, S., and Voigt, C. A. 2016. Cellulose and callose synthesis and organization in focus, what's new?. Curr. Opin. Plant Biol. 34:9-16.

Schwessinger, B., and Zipfel, C. 2008. News from the frontline: Recent insights into PAMP-triggered immunity in plants. Curr. Opin. Plant Biol. 11:389-395.

Sebastià, P., de Pedro-Jové, R., Daubech, B., Kashyap, A., Coll, N. S., and Valls, M. 2021. The bacterial wilt reservoir host Solanum dulcamara shows resistance to Ralstonia solanacearum infection. Front. Plant Sci. 12:755708.

Serpe, M., Muir, A. J., Andème-Onzighi, C., and Driouich, A. 2004. Differential distribution of callose and a $(1 \rightarrow 4) \beta$-D-galactan epitope in the laticiferous plant Euphorbia heterophylla L. Int. J. Plant Sci. 165:571-585.

Skutch, A. F. 1932. Anatomy of the axis of the banana. Botanical Gazette 93:233-258

Smakowska, E., Kong, J., Busch, W., and Belkhadir, Y. 2016. Organ-specific regulation of growth-defense tradeoffs by plants. Curr. Opin. Plant Biol. 29:129-137.

Smith, J. J., Jones, D. R., Karamura, E., Blomme, G., and Turyagyenda, F. L. 2008. An Analysis of the Risk from Xanthomonas campestris pv. musacearum to Banana Cultivation in Eastern, Central and Southern Africa. Bioversity International, Montpellier, France.

Smith, M. M., and McCully, M. E. 1978. A critical evaluation of the specificity of aniline blue induced fluorescence. Protoplasma 95:229-254.

Song, G. C., Sim, H.-J., Kim, S.-G., and Ryu, C.-M. 2016. Root-mediated signal transmission of systemic acquired resistance against above-ground and below-ground pathogens. Ann. Bot. 118:821-831.

Soukup, A., and Tylová, E. 2014. Essential methods of plant sample preparation for light microscopy. Pages 1-23 in: Plant Cell Morphogenesis: Methods and Protocols, Methods in Molecular Biology (Vol. 1080). V. Žárský and F. Cvrčková, eds. Springer Science+Business Media, New York, NY.

Ssekiwoko, F., Kiggundu, A., Tushemereirwe, W. K., Karamura, E., and Kunert, K. 2015. Xanthomonas vasicola pv. musacearum down-regulates selected defense genes during its interaction with both resistant and susceptible banana. Physiol. Mol. Plant Pathol. 90:21-26.

Ssekiwoko, F., Kunert, K., Kiggundu, A., Tushemereirwe, W. K., and Karamura, E. 2013. Musa balbisiana resists Xanthomonas wilt disease through interfering with the multiplication of Xanthomonas vasicola pv musacearum coupled with whole organ (leaf) death. Uganda J. Agric. Sci. $14: 13-25$.

Ssekiwoko, F., Turyagyenda, L. F., Mukasa, H., Eden-Green, S., and Blomme, G. 2006a. Systemicity of Xanthomonas campestris pv. musacearum in flower-infected banana plants. XVII ACORBAT International Meeting: Banana: A Sustainable Business. Joinville, Santa Catarina, Brazil, October 15-20, 2006, 789-793

Ssekiwoko, F., Tushemereirwe, W. K., Batte, M., Ragama, P. E., and Kumakech, A. 2006b. Reaction of banana germplasm to inoculum with Xanthomonas campestris pv. musacearum. Afr. Crop Sci. J. 14: $151-156$

Stone, B. A., and Clarke, A. C. 1992. Chemistry and Biology of (1->3)- $\beta$ Glucans. La Trobe University Press, Bundoora, VIC, Australia.

Stone, B. A., Evans, N. A., Bonig, I., and Clarke, A. E. 1984. The application of Sirofluor, a chemically defined fluorochrome from aniline blue for the histochemical detection of callose. Protoplasma 122:191-195.

Strugala, R., Delventhal, R., and Schaffrath, U. 2015. An organ-specific view on non-host resistance. Front. Plant Sci. 6:526.

Studholme, D. J., Wicker, E., Abrare, S. M., Aspin, A., Bogdanove, A., Broders, K., Dubrow, Z., Grant, M., Jones, J. B., Karamura, G., Lang, J., Leach, J., Mahuku, G., Nakato, G. V., Coutinho, T., Smith, J., and Bull, C. T. 2020. Transfer of Xanthomonas campestris pv. arecae and $X$. campestris pv. musacearum to X. vasicola (Vauterin) as X. vasicola pv. arecae comb. nov. and $X$. vasicola $\mathrm{pv}$. musacearum comb. nov. and description of $X$. vasicola pv. vasculorum pv. nov. Phytopathology 110:1153-1160.

Tahara, K., Norisada, M., Hogetsu, T., and Kojima, K. 2005. Aluminum tolerance and aluminum-induced deposition of callose and lignin in the root tips of Melaleuca and Eucalyptus species. J. For. Res. 10:325-333.

Torres, M. A., Jones, J. D. G., and Dangl, J. L. 2006. Reactive oxygen species signaling in response to pathogens. Plant Physiol. 141:373-378.

Tripathi, L., Atkinson, H., Roderick, H., Kubiriba, J., and Tripathi, J. N. 2017. Genetically engineered bananas resistant to Xanthomonas wilt disease and nematodes. Food Energy Secur. 6:37-47.

Tripathi, L., Odipio, J., Tripathi, J. N., and Tusiime, G. 2008. A rapid technique for screening banana cultivars for resistance to Xanthomonas wilt. Eur. J. Plant Pathol. 121:9-19.

Tripathi, L., Tripathi, J. N., and Kubiriba, J. 2016. Transgenic technologies for bacterial wilt resistance. Pages 197-209 in: Banana: Genomics and Transgenic Approaches for Genetic Improvement. Springer, Singapore.

Tripathi, L., Tripathi, J. N., Shah, T., Muiruri, K. S., and Katari, M. 2019. Molecular basis of disease resistance in banana progenitor Musa balbisiana against Xanthomonas campestris pv. musacearum. Sci. Rep. 9: $1-17$.

Tripathi, L., Tripathi, J. N., Tushemereirwe, W. K., and Bandyopadhyay, R. 2007. Development of a semi-selective medium for isolation of Xanthomonas campestris pv. musacearum from banana plants. Eur. J. Plant Pathol. 117:177-186.

Tushemereirwe, W. K., Kangire, A., Ssekiwoko, F., Offord, L. C., Crozier, J., Ba, E., Rutherford, M., and Smith, J. J. 2004. First report of Xanthomonas campestris pv. musacearum on banana in Uganda. Plant Pathol. 53:802.

Underwood, W. 2012. The plant cell wall: A dynamic barrier against pathogen invasion. Front. Plant Sci. 3:85.

Üstün, S., Bartetzko, V., and Börnke, F. 2013. The Xanthomonas campestris Type III effector Xopj targets the host cell proteasome to suppress salicylicacid mediated plant defence. PLoS Pathog. 9:1-22.

Van Den Berg, N., Berger, D. K., Hein, I., Birch, P. R., Wingfield, M. J. and Viljoen, A. 2007. Tolerance in banana to Fusarium wilt is associated with early up-regulation of cell wall-strengthening genes in the roots. Mol. Plant Pathol. 8:333-341.

Van Weemen, B. K., and Schuurs, A. H. W. M. 1971. Immunoassay using antigen-enzyme conjugates. FEBS Lett. 15:232-236.

Voigt, C. A. 2014. Callose-mediated resistance to pathogenic intruders in plant defense-related papillae. Front. Plant Sci. 5:1-6.

Voigt, C. A., Schäfer, W., and Salomon, S. 2006. A comprehensive view on organ-specific callose synthesis in wheat (Triticum aestivum L.): Glucan synthase-like gene expression, callose synthase activity, callose quantification and deposition. Plant Physiol. Biochem. 44:242-247.

Wang, Q., Shakoor, N., Boyher, A., Veley, K. M., Berry, J. C., Mockler, T. C. and Bart, R. S. 2021. Escalation in the host-pathogen arms race: A host resistance response corresponds to a heightened bacterial virulence response. PLoS Pathog. 17:1-27.

Wang, Y., Ji, D., Chen, T., Li, B., Zhang, Z., Qin, G., and Tian, S. 2019. Production, signaling, and scavenging mechanisms of reactive oxygen species in fruit-pathogen interactions. Int. J. Mol. Sci. 20:2994. 
Wi, S. J., Ji, N. R., and Park, K. Y. 2012. Synergistic biosynthesis of biphasic ethylene and reactive oxygen species in response to hemibiotrophic Phytophthora parasitica in tobacco plants. Plant Physiol. 159: 251-265.

Wissemeier, A. H., Diening, A., Hergenröder, A., Horst, W. J., and MixWagner, G. 1992. Callose formation as parameter for assessing genotypical plant tolerance of aluminium and manganese. Plant Soil 146: 67-75.

Yan, Y., Takáč, T., Li, X., Chen, H., Wang, Y., Xu, E., Xie, L., Su, Z., Šamaj, J., and Xu, C. 2015. Variable content and distribution of arabinogalactan proteins in banana (Musa spp.) under low temperature stress. Front. Plant Sci. 6:353.

Yun, M. H., Torres, P. S., Oirdi, M. E., Rigano, L. A., Gonzalez-Lamothe, R., Marano, M. a. R., Castagnaro, A. P., Dankert, M. A., Bouarab, K., and
Vojnov, A. A. 2006. Xanthan induces plant susceptibility by suppressing callose deposition. Plant Physiol. 141:178-187.

Zhang, H., Shi, W. L., You, J. F., Bian Di, M., Qin, X. M., Yu, H., Liu, Q., Ryan, P. R., and Yang, Z. M. 2015. Transgenic Arabidopsis thaliana plants expressing a $\beta-1,3$-glucanase from sweet sorghum (Sorghum bicolor L.) show reduced callose deposition and increased tolerance to aluminium toxicity. Plant Cell Environ. 38:1178-1188.

Zhou, B., Wang, J., Guo, Z., Tan, H., and Zhu, X. 2006. A simple colorimetric method for determination of hydrogen peroxide in plant tissues. Plant Growth Regul. 49:113-118.

Zvyagintseva, T. N., Shevchenko, N. M., Popivnich, I. B., Isakov, V. V., Scobun, A. S., Sundukova, E. V., and Elyakova, L. A. 1999. A new procedure for the separation of water-soluble polysaccharides from brown seaweeds. Carbohydr. Res. 322:32-39. 